Discussion Paper No. 14-049

\title{
Intangible Assets and Investments at the Sector Level - Empirical Evidence for Germany
}

Dirk Crass, Georg Licht, and Bettina Peters

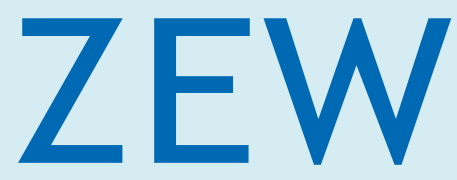

Zentrum für Europäische Wirtschaftsforschung $\mathrm{GmbH}$

Centre for European

Economic Research 
Discussion Paper No. 14-049

\section{Intangible Assets and Investments at the Sector Level - Empirical Evidence for Germany}

Dirk Crass, Georg Licht, and Bettina Peters

Download this ZEW Discussion Paper from our ftp server:

http://ftp.zew.de/pub/zew-docs/dp/dp14049.pdf

Die Discussion Papers dienen einer möglichst schnellen Verbreitung von neueren Forschungsarbeiten des ZEW. Die Beiträge liegen in alleiniger Verantwortung der Autoren und stellen nicht notwendigerweise die Meinung des ZEW dar.

Discussion Papers are intended to make results of ZEW research promptly available to other economists in order to encourage discussion and suggestions for revisions. The authors are solely responsible for the contents which do not necessarily represent the opinion of the ZEW. 


\section{Non-technical summary}

In Europe, policy has acknowledged that nowadays knowledge has become a key factor for firms to survive and grow in the increasingly globalised economy. This has found expression in the Lisbon agenda and also in the current EU2020 strategy that emphasizes that growth should be smart, sustainable, and inclusive. Smart growth means developing economies based on knowledge and innovations.

A key characteristic of knowledge is its intangible nature which makes it hard to measure its amount, quality or effects. In a recent work, Corrado et al. (2005, 2009; henceforth CHS) proposed an approach that defines three broad categories of intangible assets: Investment in computerized information (software, computerized databases), innovative property (e.g. R\&D, copyright, licences, spending on new architectural and engineering designs) and economic competencies (brand equity, firm specific human capital and organizational capital). Using the CHS approach, evidence at the macro level has shown the importance of investment in intangible assets for economic growth in many countries around the world. But it has also been revealed that there is a large heterogeneity across countries and that European countries are lagging behind the US.

Different reasons might explain this finding, leading to quite different policy conclusions. On the one hand European firms might invest less in knowledge capital than their US competitors within the same industry. On the other hand it might be explained by differences in industry structure and differences across industries in the amount and composition of intangible investment.

This paper investigates the role intangible capital plays for economic growth in different sectors in Germany. It consists of two major parts. In the first part, we aim at measuring spending and investment in intangibles at the sector level. We provide different data sources, shed light on differences across sectors but also compare these figures with investment in physical capital and with investment in intangibles in the UK as European benchmark (see Marrano and Haskel 2006). In the second part, we explore the role of intangible assets for stimulating growth at the sector level by performing growth accounting analyses.

We find that German firms have intensified their efforts to invest in intangible capital from 1995-2006 by $30 \%$ (computerized information: $+100 \%$, innovative property: $+40 \%$, economic competences: $+25 \%$ ). Nearly half of the investment in intangibles is carried out by manufacturing firms. This proportion is much higher than its share in gross output, value added or in labour input. The outstanding position of intangible capital in manufacturing is also documented by the fact that this sector invests more in intangible than intangible capital and that this proportion has even climbed from $138 \%$ to $168 \%$. Financial and business services account for about one third of all intangible investments. Though firms in this sector have expanded their investment for intangible capital, the importance relative to tangible capital is nearly unaltered. Despite this positive trend, the share of intangible investment in gross output has fallen in the two largest sectors, manufacturing (from $6.7 \%$ to $5.6 \%$ ) and financial and business services (from 9.1\% to 8.1 ).

Compared to the UK, the share of intangible investment in gross output is smaller in all sectors in Germany except for utility. A more differentiated picture, however, can be drawn when we look at distinct asset classes. For instance, manufacturing firms in Germany invest a higher proportion of gross output in R\&D and in advertising whereas investment in new designs, software, organizational structure, 
firm-specific human capital and copyright and licences are higher in the UK. In general, investment in new architectural and engineering design is consistently higher across all sectors in the UK. Computerized information is around two times larger in UK manufacturing, financial and business services and trade \& transport (similar shares in other three sectors). On the other hand, German firms invest a higher proportion of gross output in R\&D in all sectors. Advertising is also more common in Germany except for the sector trade \& transport.

Using a growth accounting framework at the sector level, we corroborate that growth in intangible assets has stimulated labour productivity growth in all sectors. The contribution varies between 0.17 (construction) and 0.59 (manufacturing) percentage points. Compared to the UK, however, intangible capital deepening seems to be somewhat smaller in absolute and relative terms in most sectors in Germany. The contribution of intangible capital turns out to be higher than that of ICT and non ICT capital separately in all German sectors, except for utility.

The results further highlight hat growth of innovative property capital is the most influential type of intangible capital for labour productivity in manufacturing and financial \& business services, followed by economic competencies and computerized information. In all other sectors, growth of intangible capital that measures economic competencies play the most prominent role for labour productivity growth, followed by innovative property capital and computerized information. The absolute contribution of investment in computerized information to growth is rather small in all sectors. But its relative growth contribution is high. The same holds for innovative property which for instance accounts for $55 \%$ of intangible investment in manufacturing, but for $65 \%$ of the total growth contribution of intangible capital. In contrast, economic competencies are relatively less growth-enhancing. In financial and business services for instance $62 \%$ of intangible investment is allotted to economic competencies. But they make up only $35 \%$ of the growth contribution of intangible capital. 


\title{
Intangible Assets and Investments at the Sector Level - Empirical Evidence for Germany
}

\author{
Dirk Crass ${ }^{\mathrm{a}}$, Georg Licht ${ }^{\mathrm{a}, \mathrm{b}}$ and Bettina Peters ${ }^{\mathrm{a}, \mathrm{b}, \mathrm{c}}$ \\ a ZEW Centre for European Economic Research, Mannheim, Germany \\ b MaCCI Mannheim Center for Competition and Innovation, Mannheim, Germany \\ c University of Zurich, Switzerland
}

Paper prepared for and forthcoming in:

Bonfour, A. and T. Miyagawa (2015), Intangibles, Market Failure and Innovation Performance, Springer.

July 2014

\begin{abstract}
This paper investigates the role intangible capital plays for economic growth in different sectors in Germany. It consists of two major parts. In the first part, we aim at measuring investment in intangibles at the sector level. We shed light on differences across sectors but also compare these figures with investment in physical capital and with investment in intangibles in the UK as European benchmark. The second part explores the role of intangible assets for stimulating growth at the sector level by performing growth accounting analyses. We find that German firms have boosted investments in intangible capital from 1995-2006 by 30\%. Furthermore, results reveal differences in the investment patterns among the UK and Germany. In nearly all sectors investments in design and computerized information are larger in the UK. In contrast, German firms invest a higher proportion of gross output in R\&D in all sectors, and advertising is also more common except for the sector trade \& transport. Intangible assets have stimulated labour productivity growth in all sectors. The contribution varies between 0.17 (construction) and 0.59 (manufacturing) percentage points. In manufacturing, financial and business services innovative property capital is the most influential type of intangible capital for labour productivity, followed by economic competencies and computerized information. In all other sectors, economic competencies play the most prominent role for labour productivity growth.
\end{abstract}

Keywords: Intangible assets, economic growth, sector

JEL-Classification: E22, 047, L60, L80

Acknowledgements:

Financial support has been provided by the COINVEST project, www.coinvest.org.uk, funded by the European Commission Seventh Framework Programme, Theme 9, Socio-economic Science and Humanities, grant number 217512. We are grateful for useful comments and suggestions made by participants at COINVEST seminars in Lisbon, Mannheim, Paris, Stockholm, and London. We particularly thank Jonathan Haskel and Anarosa Pesole for their comments and for sharing Stata programs. Any errors remain those of the authors. 
In Europe, policy has acknowledged that nowadays knowledge has become a key factor for firms to survive and grow in the increasingly globalised economy. This had already found expression in the last decade in the Lisbon agenda that aimed to make the EU "the most competitive and dynamic knowledgedriven economy by 2010" and also in the current EU2020 strategy that emphasizes that growth should be smart, sustainable, and inclusive. Smart growth means developing economies based on knowledge and innovations. Thus strengthening the efficiency and competitiveness of firms in the knowledge driven economy is a major challenge that the EU economies are currently confronted with.

A key characteristic of knowledge is its intangible nature which makes it hard to measure its amount, quality or effects. Furthermore, investments in such intangible knowledge assets may take place in very different forms. In a recent work, Corrado et al. (2005, 2009; henceforth CHS) propose how to define and measure intangible assets. They distinguish three broad categories of intangibles: Business investment in computerized information, innovative property and economic competencies: Computerized information consists of investments for computer software and computerized databases. Innovative property reflects scientific knowledge embedded in patents, licences, and general know-how (not patented) on the one hand but also the non-scientific innovative and artistic content in commercial copyrights, licences, and designs on the other hand. This is captured by the following five components: expenditure for R\&D in natural and social sciences, mineral exploration, copyright and licences, new product development costs in the financial industry and spending on new architectural and engineering designs. Finally, economic competencies involve investments aimed at raising productivity and profitability other than software and R\&D. Corrado et al. specified such economic competencies as value of brand names and other knowledge embedded in firm-specific human and structural organizational resources.

Using the CHS approach, recent evidence at the macro level has shown the importance of investment in intangible assets for economic growth in many countries around the world. However, it has also been revealed that many European countries are lagging behind the US figures. For instance, Corrado et al. (2009) report investments in intangible assets that amount to $11.7 \%$ of GDP in the US. Investment in intangibles is even larger than the investment in physical capital. Fukao et al. (2009) reported a corresponding proportion for the Japanese economy of $11.2 \%$ for the period 2000-2005. Within Europe, the UK invests the highest proportion of GDP for intangible assets, but which is still roughly 1.5 percentage points below the US (10.1\%; Marrano and Haskel, 2006). In other European countries it is even less: 9\% in Sweden (Edquist, 2011), 7.0\% in Germany (Crass et al., 2010), 6-7\% in France (Delbecque and Nayman, 2010), 5.2\% in Spain and Italy (Hao et al., 2009). A similar pattern emerges for the contribution of intangible assets to growth. In the US, investment in intangible assets has stimulated labour productivity growth by 0.84 percentage points, whereas the contribution in European countries varies between 0.6 to 0.2 percentage points ( 0.58 in UK, 0.53 in Germany, 0.34 in Italy and 0.19 in Spain). One exception is Sweden where intangible capital has accounted for 1.8 percentage points of the labour productivity growth rate.

There might be different reasons why European countries are lagging behind and which might lead to quite different policy conclusions. On the one hand European firms might invest less in knowledge capital than their US competitors within the same industry. Another explanation of why these figures 
differ across countries might be because of varying industry structures in these countries and the fact that industries ${ }^{1}$ might behave differently in terms of the amount and composition of intangible investment. Of course, it might also be a mixture of both. The empirical evidence, however, on how much sectors invest in which type of intangible asset and how this affects economic growth at the sector level, is scarce up to now. In a recent study, Goodridge et al. (2012) provide evidence that the ratio of intangible investment to value added is highest in the manufacturing sector in the UK. This finding was corroborated by Niebel et al. (2013) for a larger set of 10 European countries. In a cross-country comparison of Japan and South Korea, Chun et al. (2012) likewise find that the share of intangible investment in value added is higher in Japan for many industries with the exception of some service sectors. For Japan, they furthermore estimate the impact of intangible capital on total factor productivity (TFP). Their results show that intangible capital has stimulated productivity growth in manufacturing after the IT revolution, i.e. for the period 1996-2008. Distinguishing between the three components of intangible capital, it turns out that innovative property was the main driver of productivity growth in manufacturing whereas economic competences and, somewhat surprising, computerized information did not foster TFP growth. In contrast to their findings for the later period, they did not find any significant productivity effects in manufacturing for the earlier period 1980-1995. Likewise their findings did not suggest a positive effect for service industries in Japan. For Europe, Niebel et al. (2013) likewise show a significant effect of intangible capital on productivity growth in manufacturing. For services, their results also indicate a positive productivity effect though their results are less robust across different specifications. Their estimated output elasticities of intangibles range between 0.1 and 0.2. These values are lower than those found in studies using aggregate data. But they are larger than the factor compensation share of intangible capital. This is usually seen as an indicator for the existence of spillovers of intangible capital or unmeasured complementarities between tangible and intangible capital. Not in general, but for ICT capital and firm-specific human capital (training), O'Mahony and Peng (2011) provided industry-level evidence for the complementarity hypothesis.

This chapter investigates the role intangible capital plays for economic growth in different sectors in Germany. It consists of two major parts. In the first part, we aim at measuring spending and investment in intangibles at the sector level. We will provide different data sources, shed light on differences across sectors but also compare these figures with investment in physical capital and with investment in intangibles in other countries. In the second part, we explore the role of intangible assets for stimulating growth at the sector level by performing growth accounting analyses.

Section 2 presents data sources for each category of intangible assets as well as their availability at the sector level and over time in Germany. We will furthermore show the development of investment in intangibles at the sector level. Whereas the first three subsections discuss figures for each single category, the last subsection 2.4 will condense the information by looking at the three main broad categories innovative property, economic competencies and computerized information, i.e. their sharing out among sectors and their development within sectors over time. Subsequently, section 3 will compare investments in intangible assets with those in tangible capital in German sectors. In order to internationally assess investments in intangible assets in German industries, we will compare our results with sector-level figures from the UK in section 4 . Section 5 will examine the role of intangible capital in explaining productivity growth at the sector level by performing growth accounting analyses. Besides

${ }^{1}$ In the following, the terms sector and industry are used interchangeably. 
studying industry-level sources of economic growth, we will trace the sources of aggregate productivity growth and input factor growth to their industry origins. Section 6 finally summarizes our main findings.

\section{Measurement of intangible investment by category and sector}

This study follows the methodological framework set up by CHS (2006). We furthermore follow Gil and Haskel's (2008) breakdown of industries for the UK. We exclude all non-business sector categories (public administration, education, health, personal services, private households and extra-territorial). For the remaining business sector (BuSec), we distinguish six main industries of interest. Using the European-wide industry classification NACE Rev. 1.1, we define: (1) Agriculture, fishing \& mining (in the following: Agriculture \& mining, AgMin, NACE: A,B,C), (2) manufacturing (Mfr., NACE: D); (3) electricity, gas \& water (in the following: Utility, NACE: E), (4) construction (Cons, NACE: F), (5) wholesale and retail, hotels and restaurants, transport and communications (in the following: trade \& transport, RetHtTrn, NACE: $G, H, I$ ) and (6) financial intermediation and business Services (FinBsSvc, NACE: J, K). For some but not all time series a more detailed industry breakdown would have been available.

To give an overview of the importance of each of the industries, Table 1 depicts the share in aggregate gross output, value added and labour input (hours worked). The figures show that in Germany manufacturing makes up the largest share in aggregate gross output. Nearly $44 \%$ of total gross output has been produced by manufacturing in the period 1997-2006, followed by the sectors trade \& transport and financial \& business services, both having a share of about $22 \%$. On the contrary, the financial \& business service sector present the largest proportion in value added (37\%). Its share is roughly 7 and 13.5 percentage points higher than the value added share of manufacturing and trade \& transport sector, respectively. Compared to manufacturing and financial and business services, the sector trade \& transport is more labour-intensive. We can observe the highest share of total hours worked in the sector trade \& transport (35\%), followed by manufacturing (28.5\%) and financial \& business services (21\%). The industry share of construction amounts to $6-10 \%$, depending on the indicator. The other two sectors are rather small with a share of $2-3 \%$.

Table 1: Industry share in gross output, value added and labour, 1997-2006

\begin{tabular}{l|cccccc}
\hline Industry share in & $\mathbf{1}$ & $\mathbf{2}$ & $\mathbf{3}$ & $\mathbf{4}$ & $\mathbf{5}$ & $\mathbf{6}$ \\
AgMin & Mfr. & Utility & Cons. & RetHtTm & FinBsSvc \\
\hline Gross output & 0.022 & 0.439 & 0.027 & 0.072 & 0.220 & 0.219 \\
Value added & 0.018 & 0.294 & 0.028 & 0.062 & 0.231 & 0.367 \\
Labour & 0.045 & 0.285 & 0.011 & 0.102 & 0.348 & 0.209 \\
\hline
\end{tabular}

Notes: Presented are average annual industry shares. Data: EU KLEMS. Own calculation.

Figure 1 demonstrates that the annual growth rates in value added per hour worked indeed vary quite a lot across sectors in Germany. The open question that we address in this study is to what extent does intangible capital (or do other factor inputs) account for these differences and to what extent do sector differences translate to aggregate productivity growth?

In the following, we present data sources and estimated time series for different categories of intangible assets for the six industries. With respect to data sources, this work draws on previous work done at the macro level in Germany (see Crass et al., 2010). Crass et al. performed various sensitivity analyses for measuring intangible capital in Germany using alternative data sources, in particular for measuring new development costs in the financial industry, brand equity, and firm-specific human capital. All data 
sources are described in more detail with respect to data availability, main advantages and drawbacks in Crass et al. Hence, we also refer the interested reader to this paper for further information.

Figure 1: Annual growth rates in value added per hour worked by industries, 1991-2008

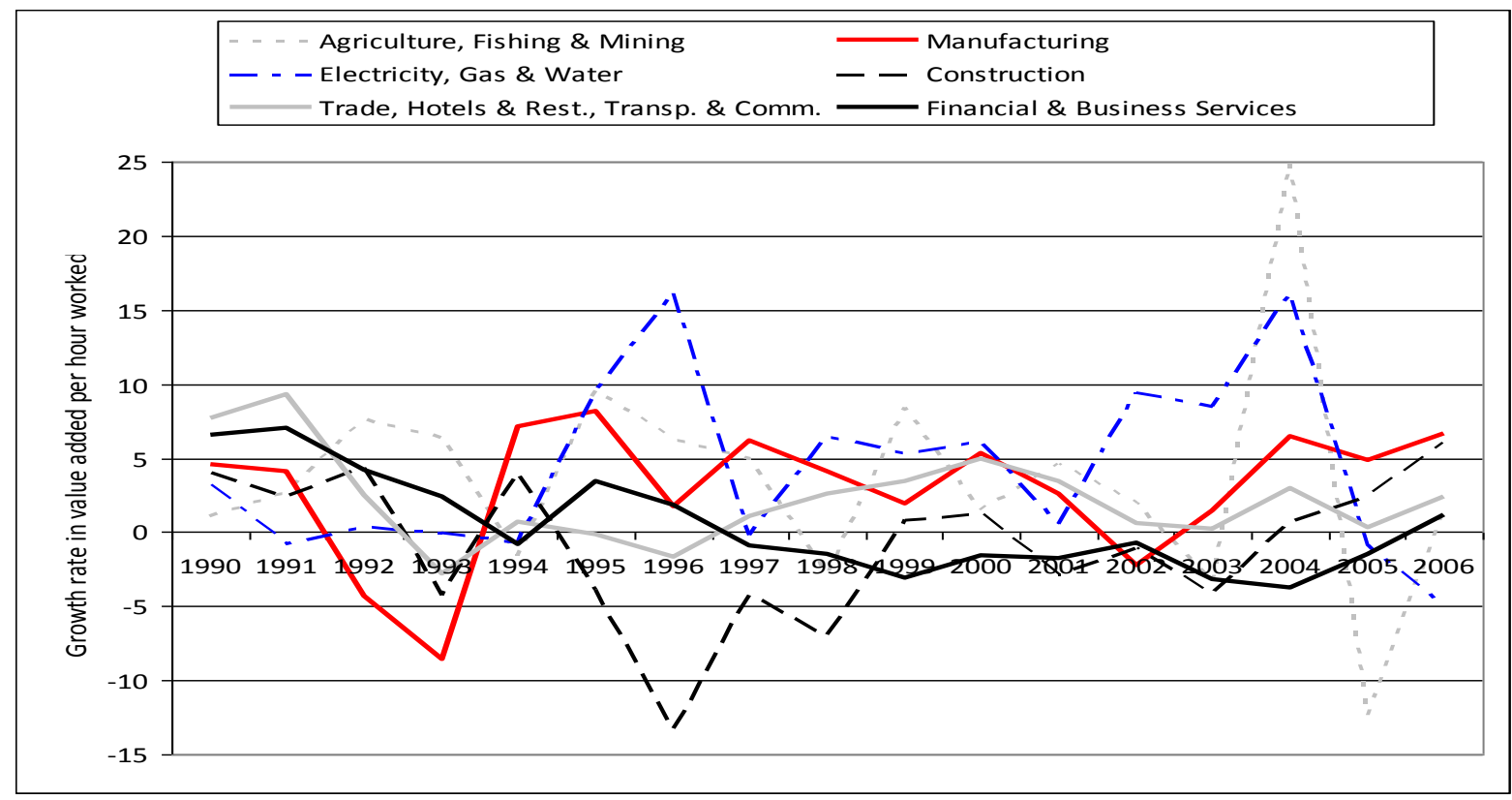

Source: EU KLEMS Nov2009 Release; own calculation.

\subsection{Computerized information}

The first category, computerized information, reflects knowledge embedded in computer programs and computerized databases. Therefore, computerized information is made up of two components, the investment in purchased and own account computer software and the investment in new computerized databases.

\subsubsection{Investment in own account computer software}

Compared to most of the other intangible assets, computer software is already viewed as investment in the German national accounts. For own account computer software we use data provided by the EU KLEMS November 2009 Release. EU KLEMS publishes estimates of the investments in software at the industry level in Germany for the period 1991 to $2007 .{ }^{2}$ In case where figures were not available in EU KLEMS using the 6-industry classification (for instance for sector agriculture and fishing (A-B) and mining (C) which we summarize to $A-C$ ), the aggregation of indices across sectors has been done using a Tornqvist-weight. This procedure applies to sector 1,5 and 6 . As in Corrado et al. $(2005,2009)$ we have furthermore assumed that $100 \%$ of software spending can be regarded as investment.

\footnotetext{
2 At EU KLEMS, the following industry breakdown is given based on the industry classification NACE Rev. 1.1: NACE A-B (agriculture \& fishing), C (mining and quarrying), D (manufacturing that is further split into the NACE industries 15-16, 17-19, 20, 21-22, 23, 24, 25, 26, 27-28, 29, 30-33, 34-35, 36-37), E (electricity, gas and water supply), F (construction), G (wholesale and retail trade, further broken down into 50, 51 and 52), $\mathrm{H}$ (hotels and restaurants), I (transport and storage, further broken down into 60-63 and 64), J (financial intermediation), $\mathrm{K}$ (real estate, renting and business activities, further split into 70 and 71-74) as well as the public and private sector $(75,80,85,90,95,99)$. However, for comparability reasons we have consolidated the information into the six industries. Note software investment carried out in the public and private household sector like community social and personal services has been excluded.
} 
Table 11 in the Data Appendix depicts the distribution of software investment across sectors in Germany. In total, investment in software has been more than doubled from 8 bn $€$ in 1991 to nearly 18 bn $€$ in 2007 with a slight slump after the new economy boom within the period 2002-2004. However, a more detailed look at the figures reveals that the development turns out to be quite different across industries. In construction, for instance, investment in software declined over time leading to a fall in the proportion of software investment accounted for by this sector from $4.7 \%$ to $1.9 \%$. On the other side, financial and businesses services boosted their software investment from 1.6 bn $€$ in 1991 to 6.0 bn $€$ in 2007 (with a peak of 6.2 bn $€$ in 2001). As a consequence, the proportion of software investment undertaken by this sector has increased from $20 \%$ to $34 \%$. Though manufacturing firms have raised their investment in software as well (from 3.5 to $5.7 \mathrm{bn} €$ ), they have lost in terms of relative importance. The proportion of software investment that is carried out in manufacturing has declined from $44 \%$ to $32 \%$. Software investment in trade \& transport has also increased leading to a share in overall investment that fluctuates around $25 \%$.

\subsubsection{Investment in new computerized databases}

Information for new computerized databases is gathered from the German turnover tax statistics. The overall expenditure for new databases is measured by the sales of NACE class 72.4. Unfortunately, this data source does not contain information about the customers of sector 72.4. Following Gil and Haskel (2008), we distribute the overall expenditure across the six sectors using yearly input-output tables provided by the Federal Statistical Office of Germany. Since input-output tables are only available at the 2-digit level in Germany, we use industry 72 as proxy. As was done previously in the case of software, we consider all spending as investment. Table 11 in the Data Appendix shows that the investment in new computerized databases constitute only a very small fraction of the overall amount invested in computerized information in Germany. But the investment in computerized databases has significantly increased over the course of the past decade. We though do not observe a continuous rise but a rather strong slump after the new economy boom in the period 2003-2005 from which the German economy has recovered from 2006 onwards. Interestingly, this picture emerges in all sectors to more or less the same extent implying that the distribution across industries remains quite stable over time. More than half of the investment in new databases (around 56\%) is made in the financial and business service sector and just around one fifth in manufacturing.

\subsection{Innovative property}

The second broad category of intangible assets summarizes investments in innovative property. It covers the amount firms invest in research and development, mineral exploration, copyright protected work, licences and new designs.

\subsubsection{Scientific research and development (R\&D)}

Compared to other types of intangible capital, data on business enterprise research and development (R\&D) expenditure have been collected for many years already following the guidelines set out by the 
Frascati manual (OECD, 2002). Data have been taken from ANBERD. ${ }^{3}$ As suggested by CHS, we consider total spending on R\&D as investment. Table 12 in the Data Appendix illustrates the development of R\&D investment by sector in Germany for the period 1991-2008. While R\&D investment was rather stable up to the mid-nineties, we do observe a steady increase since then. The overwhelming majority of scientific $R \& D$ is conducted in manufacturing. Roughly $90 \%$ of scientific R\&D was carried out in this sector. The proportion of R\&D performed in manufacturing has fallen over time while it has increased in business related services from $1.7 \%$ in 1991 to $9.4 \%$ in 2008. In absolute figures, R\&D mounted from 0.46 bn $€$ in 1991 to 4.3 bn $€$ which corresponds to a rise by more than $800 \%$. However, these figures should be taken with care since in part they reflect an artificial development which is due to the fact that the coverage of service firms within the R\&D surveys has been improved a lot since the end of the nineties.

\subsubsection{Mineral exploration}

Mineral exploration should capture all costs involved in the process of finding ore which can be exploited in the future and which will thus lead to sales in the future. Expenditure on current exploitation should not be included. Information stems again from the German turnover tax statistic. The sales of category "test drilling and boring" (45.12) are counted as expenditure on mineral exploration. An industry breakdown is not necessary. We follow Gil and Haskel (2008) and classify expenditure on mineral exploration as belonging to sector Agriculture, Fishing \& Mining. Furthermore, we follow CHS and view all spending on mineral exploration as investment. Table 13 depicts the amount of investment. Mineral exploration is the least important type of intangible investment in Germany. Less than 0.2 bn $€$ is spent for it though it has significantly gone up since the mid-nineties.

\subsubsection{Copyright and licence costs}

Information-sector industries like book publishers, motion picture producers, sound recording producers, and broadcasters also spend a lot of money for developing and introducing new products. This spending for new product development is usually not regarded as scientific R\&D and thus not included in R\&D figures. Assuming that new product investment by the information sector usually leads to a copyright or licence, they suggest a category of intangible asset that is called copyright and licence costs. CHS estimated copyright and licence costs by twice the new product development costs of the motion picture industry (source: Motion Picture Association). Hao and Manole (2008) used data from Screen digest whereas Morrano and Haskel (2006) make use of information from the national accounts in the UK. In Germany, the national accounts only provide a combined figure on investment in immaterial assets which consists of software and database, copyright and licences, livestocks, economically useful plants and costs for the transfer of undeveloped sites (Statistisches Bundesamt, 2010b). Since we cannot identify copyright and licence costs separately from the national accounts, we therefore estimate the costs using the category "motion picture and video production" (NACE 92.11) of the German turnover tax statistic. ${ }^{4}$ In the industry classification NACE Rev 1.192 .11 is assigned to

\footnotetext{
${ }^{3}$ In Germany, the R\&D survey is conducted by the Stifterverband. It feeds the Analytical Business Enterprise Research and Development database (ANBERD).

${ }^{4}$ For comparison, based on national accounts Hao et al. (2009) estimated copyright and licence costs to be roughly 4.94 bn $€$ in Germany in 2004. We estimate costs of roughly 4 bn $€$. The national accounts estimated gross investment in immaterial goods in the private sector at 22.9 bn $€$ (Statistisches Bundesamt 2006), taken into account that software already accounted for 16 bn $€$, the upper limit for copyright and licences is $6.9 \mathrm{bn} €$.
} 
services (recreational, cultural and sporting activities) while publishing is assigned to manufacturing. Gil and Haskel (2008) decided to relate total spending to the manufacturing sector and we follow this approach. We treat all spending for copyright and licences as an investment. Table 13 illustrates the development of estimated copyright and licence costs over the period 1992-2008. They have increased up to 1998 but have experienced a significantly fall off since then from 6.8 to 3.7 bn $€$ in 2008 .

\subsubsection{Development costs in the financial industry}

The financial industry also spends a lot of money for developing and introducing new financial products. As for the information-sector industries, most of these outlays for new product development are usually not regarded as scientific R\&D and are thus not included in R\&D figures. Nakamura (2001) proxied new product development costs in the financial services industry as a proportion of the non-interest expenses of banks and non-depository institutions. He assumed $50 \%$ without giving a sound economic explanation. Corrado et al. (2009) broadened the coverage to include other financial institutions (security and commodity brokers and other financial investments and related activities). Since there is no broad survey data in the US on the resources banks and insurance companies devote to new product development, they proposed as a rudimentary guess to use as proxy a share of $20 \%$ of all intermediate purchases reported in the BEA's data on gross output and value added by industry. In contrast to the US, the Community Innovation Surveys (CIS) provide data on innovation expenditure in the financial industry for all European countries. The methodology is based on the Oslo manual (OECD and Eurostat, 2005). The German contribution to the CIS is the Mannheim Innovation Panel (MIP) which is carried out annually (see Peters and Rammer 2013). As an alternative to the proxies used in the literature we therefore estimate the development costs using the innovation expenditure in the financial industry. Innovation expenditure is related to new products and processes. Process innovations are often associated with the acquisition of new machines which are counted as tangible capital at the same time. To avoid double counting we subtract the expenditure which is related to the acquisition of new machines for product and process innovations from total innovation expenditure. Following $\mathrm{CHS}$, new product development costs of the financial industry developing new products are considered as investment. We furthermore relate these costs completely to the sector financial intermediation and business services.

The time series on investment in financial services innovation is illustrated in Table 13. Between 1995 and 1999, German banks and insurances have raised their investments in innovation from 3.9 bn $€$ to $6.6 \mathrm{bn} €$. In the last decade, however, we observe a continuous fall off and in 2008 investment for innovation were even below the figures for 1995. The steep increase around the millennium can be explained by new opportunities that emerged at that time due to new information and communication technologies (e.g. internet banking, telephone banking, etc.). It turns out that CIS data leads to considerable smaller estimates of investment in financial services innovation than the alternative measure. In 1995 our estimate is just 47\% of that of Hao and Manole (2008). This proportion has even fallen to $25 \%$ in 2008.

\subsubsection{New architectural and engineering design}

Following Corrado et al. (2009) we measure new architectural and engineering design as half of the turnover of the architectural and design industry (NACE class 74.2). Turnover data are derived from the German turnover tax statistics. Like for databases, we have to allot sales to the six industries using 
input-output tables (based on industry 74). This provides us with an estimate of investment in new architectural and engineering design at the sector level. As Table 14 in the Data Appendix shows, the amount firms invested in new architectural and engineering designs was rather stable over the period 1992-2004, ranging between 18 and 19 bn $€$. This rather stable development is surprising since we expected the increasing trend to outsource design activities to be reflected in the time series. Since 2004 , however, we observe a continuous increase up to $22 \mathrm{bn} €$ in 2008. The figures also reveal that the distribution across sectors is very stable over time. In part this might be due to the fact that we use input-output tables to get sector-level estimates. 37-39\% of all investment for new designs has been undertaken by manufacturing firms. The proportion is even slightly higher in financial and business services at about $40-42 \%$. Roughly $1.8 \%$ of this intangible item is produced by agriculture $\&$ mining and utility, respectively. Trade and transport account for $14 \%$.

\subsection{Economic competencies}

The third and final broad category is economic competencies. It includes spending on strategic planning, spending on redesigning or reconfiguring existing products in existing markets, investments to retain or gain market share, and investments in brand names. How we measure them at the sector level will be explained in the following subsections.

\subsubsection{Brand equity}

Corrado et al. $(2005,2009)$ propose a broad conceptualization of marketing activities by including both advertising and market research. Advertising expenditure is seen as the firm's primary investment into brand equity. We use data on external (purchased) gross advertising expenditure published by the Central Association of the German Advertising Industry (ZAW). Gross advertising expenditures comprise net revenues of the media firms (distribution costs of advertising) and production costs of advertising, excluding half of the advertisement on newspapers. Firms may not commission all advertising activities to outside media firms but some of them may be carried out in-house as well. Based on information gathered within the MIP, we estimate that own-account advertising outlays make up roughly $15 \%$ of external advertising expenditure. Purchased market research is estimated using the sales of industry 74.13.1 reported in the German turnover tax statistics. Unlike all previous studies we exclude 74.13.2 which is related to research for public opinion polling since these outlays do not increase brand equity. Whereas Corrado et al. $(2005,2009)$ assumed that own-account market research equals purchased market research we use the same $15 \%$ premium as for advertising. To get sector level estimates, we furthermore have to distribute total expenditure for both intangible assets to the six industries using input-output tables (using industry 74). Finally, we get from spending to investment figures by assuming that $60 \%$ of the outlays can be considered as investment while the rest is viewed as short-term focussed (see Landes and Rosenfield, 1994, Corrado et al., 2009). Table 15 in the Data Appendix presents investment in brand equity in Germany by sector. German firms have increasingly invested in brand equity up to 2000. Maybe not surprisingly, investments have gone down with the beginning of the recession in 2001. Since 2004 we can see a slight recovery, however, even in 2008 the investment was still below the 2000 value. Due to the fact that we are forced to use input-output tables at the 2-digit industry level, we estimate the same (and rather stable) distribution across industries as for new architectural and engineering design. In particular, we estimate that about $38 \%$ of the investment in 
marketing is done in manufacturing, $14 \%$ in trade and transport and $41 \%$ in financial and business services.

\subsubsection{Firm-specific human capital}

The costs of employer-provided worker training are the second important ingredient of economic competencies. Investment in firm-specific human capital consists of initial vocational training and continuing vocational training. We use the reports on the financing of education to calculate the costs of initial vocational training in the business sector. ${ }^{5}$ Expenses for continuing vocational training comprises direct and indirect costs. Direct costs include operating expenses for organizing and running further training whereas indirect costs reflects the costs of the continued payment of wages if the further training takes place within normal working hours. We make use of the Mannheim Innovation Panel (MIP) to estimate direct (internal and external) costs of continuing vocational training at the 2-digit industry level. We calculate the indirect costs of continuing vocational training by using the proportion of direct costs to total costs which is on average 35\% (see Werner 2006). We furthermore follow CHS and assume that total spending has investment character. Table 15 illustrates overall investment in firmspecific human capital by sector. The German business sector has invested between 30 and 35 bn $€$ each year in initial and continuing vocational training. Manufacturing accounted for roughly one third of the investment in firm-specific human capital. This proportion is slightly higher than its proportion in labour input (see Table 1). Its share has increased from 32\% to $37 \%$ in 1998 but has dropped since then to $30 \%$ in 2006. The reverse pattern can be observed for financial and business services. Their share amounts to $35 \%$ at the beginning and end of the period but has fallen in between to $29 \%$. Though trade $\&$ transport is the most labour intensive sector, only around one fourth of total investment in firm-specific human capital is performed in this sector. The figures elicit that this share is quite stable over time in Germany. Construction accounted for $4 \%$ and utility for $2-3 \%$.

\subsubsection{Organizational structure}

The final intangible item is aimed at capturing organizational capital which is also viewed as an important driver for gaining competitive advantage. Investment in organizational capital includes outlays for purchased organizational structure as well as expenditure for own-account organizational structure. To measure investment in purchased organizational structure, we follow Gil and Haskel (2008) who suggested employing the revenues of the management consulting industry. That is, we use sales of the management consulting industry (74.14.1) provided by the German turnover tax statistics. Using sales for a specific industry again implies that we do not have an industry breakdown and therefore employ the input-output table (for industry 74 ) to get sector-level estimates for the six industries. Like previous studies, we furthermore assume that $80 \%$ of purchased organizational structure expenditure can be considered as investment. The most salient finding that can be gauged from Table 16 in the Data Appendix is that investment in purchased organization structure has more than doubled within fourteen years. It has been raised from 8 bn $€$ in 1994 to 20 bn $€$ in 2008 with a severe slump in the recession period between 2001 and 2004. Since we use the same input-output-table information to allot the investment onto the sectors, the distribution across sectors is the same as for architectural and

\footnotetext{
5 Until 2007, these reports had been published by the Bund-Länder-Kommission für Bildungsplanung und Forschungsförderung - BLK. The German Federal Statistical Office has taken on the job of publishing the report from 2008 on.
} 
engineering design or marketing investment. Future research would benefit a lot if more detailed 3-digit input-output tables are available.

Admittedly, the expenditure on own-account organizational structure is only roughly measured. We follow the general approach of Corrado et al. (2009) and assume that $20 \%$ of a manager's time is spent on organizational building activities. Thus $20 \%$ of the managers' earnings can be considered as spending on own-account organizational structure. Data sources on managers' earnings can be gathered from Table 9. Since an industry breakdown is not available, we applied once more input-output table (using industry 74), and thus we implicitly assume that the breakdown is the same for investment in purchased and own-account organizational structure. Table 16 depicts the development over the period 19912007. Investment in own account organizational structure has been continuously increased whereas the distribution across sectors has remained rather stable.

\subsection{Summary: Computerized information, innovative property and economic competencies}

Having presented data and figures on intangible investment for each category at the sector level, this section condenses the information by looking at the three broad categories computerized information, innovative property and economic competencies and their distribution across industries in Germany. Since computerized information mainly consists of investment in software, findings are similar as in section 2.1. Most strikingly, firms have intensified their efforts to invest in computerized information by nearly $100 \%$ in the period 1994 to 2007 as can be seen from Figure 2. At the same time, a shift has taken place from manufacturing towards business services. The share of software investment that is accounted for by manufacturing has declined from $36 \%$ to $32 \%$ whereas it has increased in the service sector industries. The increase in software investment was particularly strong in financial and business sector services in the first half of the period. In the meantime, firms in trade and transport have caught up. They account for $27 \%$ of all software investment in Germany.

Figure 2: Distribution of computerized information by industries, 1994-2007

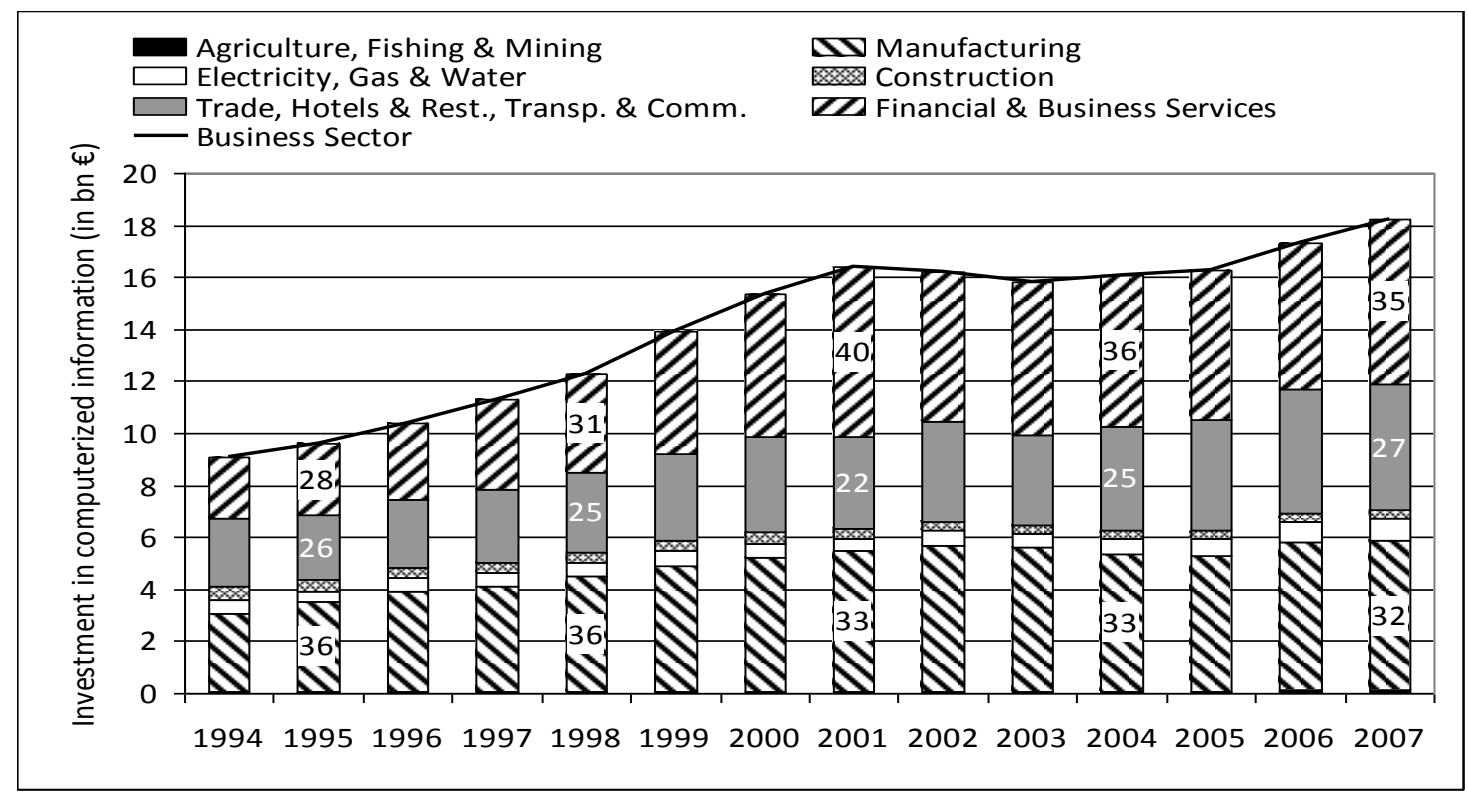

Sources: See Table 9; own calculation. 
Innovative property is highly concentrated in two industries, manufacturing and financial and business services as it is shown in Figure 3. The overall trend in investment in innovative property is increasing. From 1995 to 2008 investment in innovative property has grown by $40 \%$. This trend can be observed in all sectors to more or less the same extent since the distribution across industries is nearly unaltered over time. Around $70 \%$ of total investment in innovative property is carried out in manufacturing, predominately in terms of scientific R\&D. But the share of financial and business services is nonnegligible. They make up around $22 \%$ of innovative property investment in the German economy, mainly for new design and financial services innovation.

Figure 3: Distribution of innovative property across industries, 1995-2008

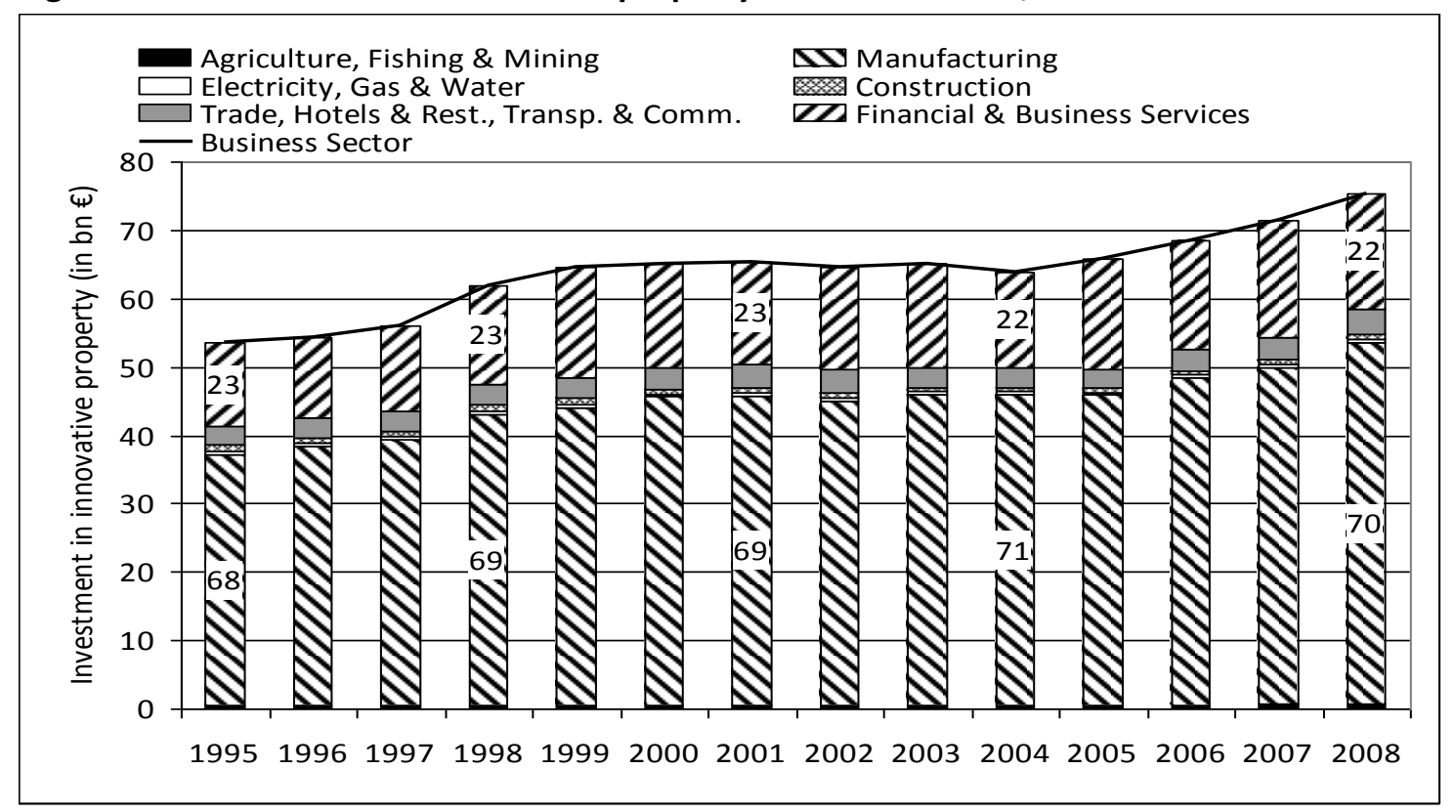

Sources: See Table 9; own calculation.

Investments in economic competencies are less concentrated across sectors than those in innovative property as can be seen from Figure 4. Furthermore, the distribution across industries is quite stable over the period which is in part due to way how we estimate sector-level investment using input-output tables. If at all, the share of manufacturing and trade \& transport has slightly increased whereas it has dropped for financial and business services. $35-37 \%$ of all investments aimed at improving economic abilities have been carried out in manufacturing. Financial and business service firms accounted for nearly the same amount. Around one fifth of the investment in economic competencies has been carried out in firms operating in trade \& transport.

Finally, Figure 5 delineates the relative importance of each intangible item within the industries. We use the year 2004 as reference year. In the German business sector, around 38\% of the investments in intangible capital are related to scientific R\&D, another $10 \%$ to investments in software and databases. However, roughly half of the investment in intangible capital is devoted to improving economic competencies $(52 \%)$, a category that is not accounted for by national accounts. The relative importance of different types of intangible assets varies quite a lot across sectors. In manufacturing, firms direct $39 \%$ of their investments in intangibles to economic competencies. This share is above $60 \%$ in all other industries, being highest in construction with $78 \%$. Manufacturing firms do not only perform most of the $R \& D$, but $R \& D$ is likewise the most important type of intangible asset in this sector. Investments in innovative property make up 55\% of all intangible investment. Compared to other intangible assets, 
innovative property is far less important in financial and business services (27\%) and agriculture and mining (28\%). In the other three sectors innovative property accounts for about $13-14 \%$ of intangible investment. We can observe a strong variation in the relative importance of software and databases, ranging from $5 \%$ in agriculture and mining to $17 \%$ in trade and transport and even $21 \%$ in utility. Although most of the investment in software and databases are performed by firms in manufacturing and financial and business services, computerized information constitutes only a relatively small proportion in intangible investment in these industries (manufacturing: 6\%, financial and business services: $11 \%)$.

Figure 4: Distribution of economic competencies across industries, 1995-2006

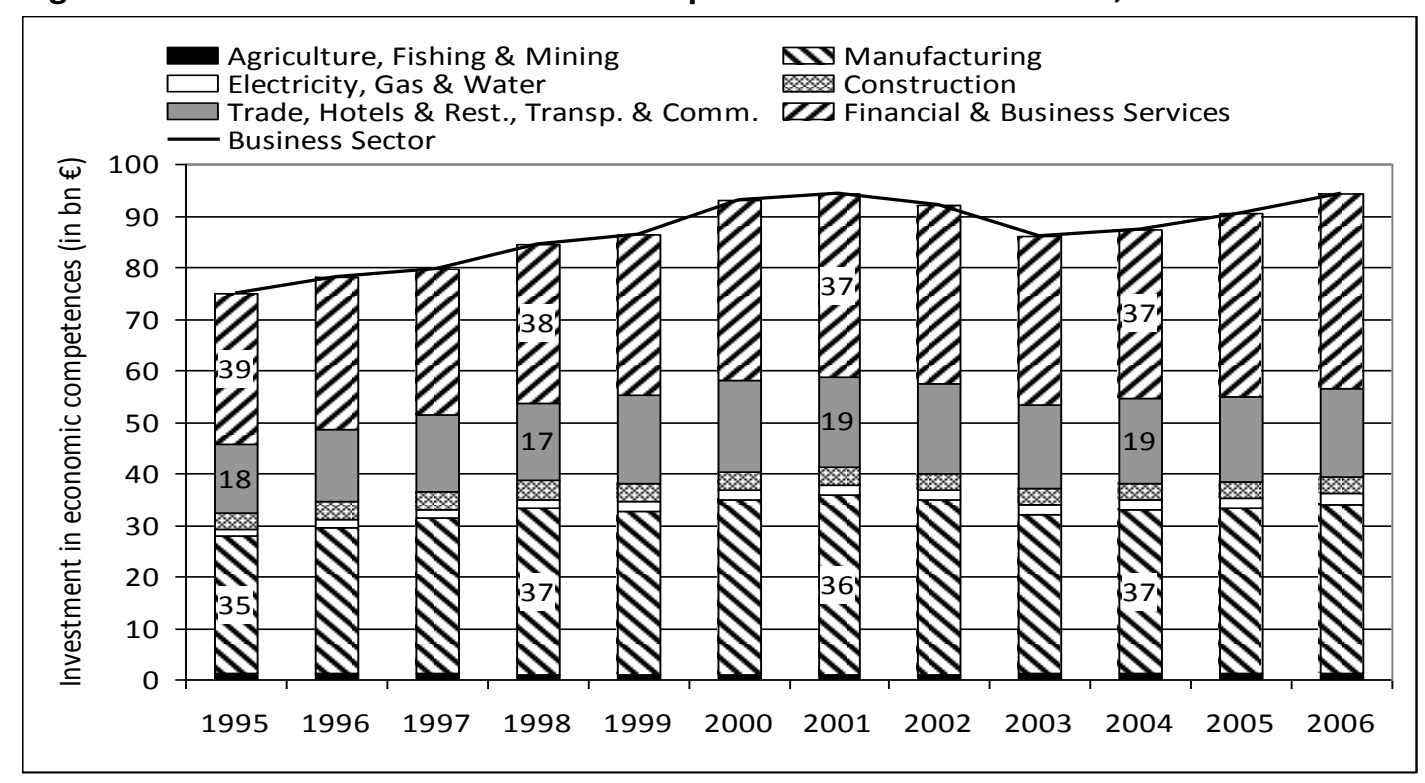

Sources: See Table 9; own calculation.

Figure 5: Distribution of intangible investments by sector, 2004

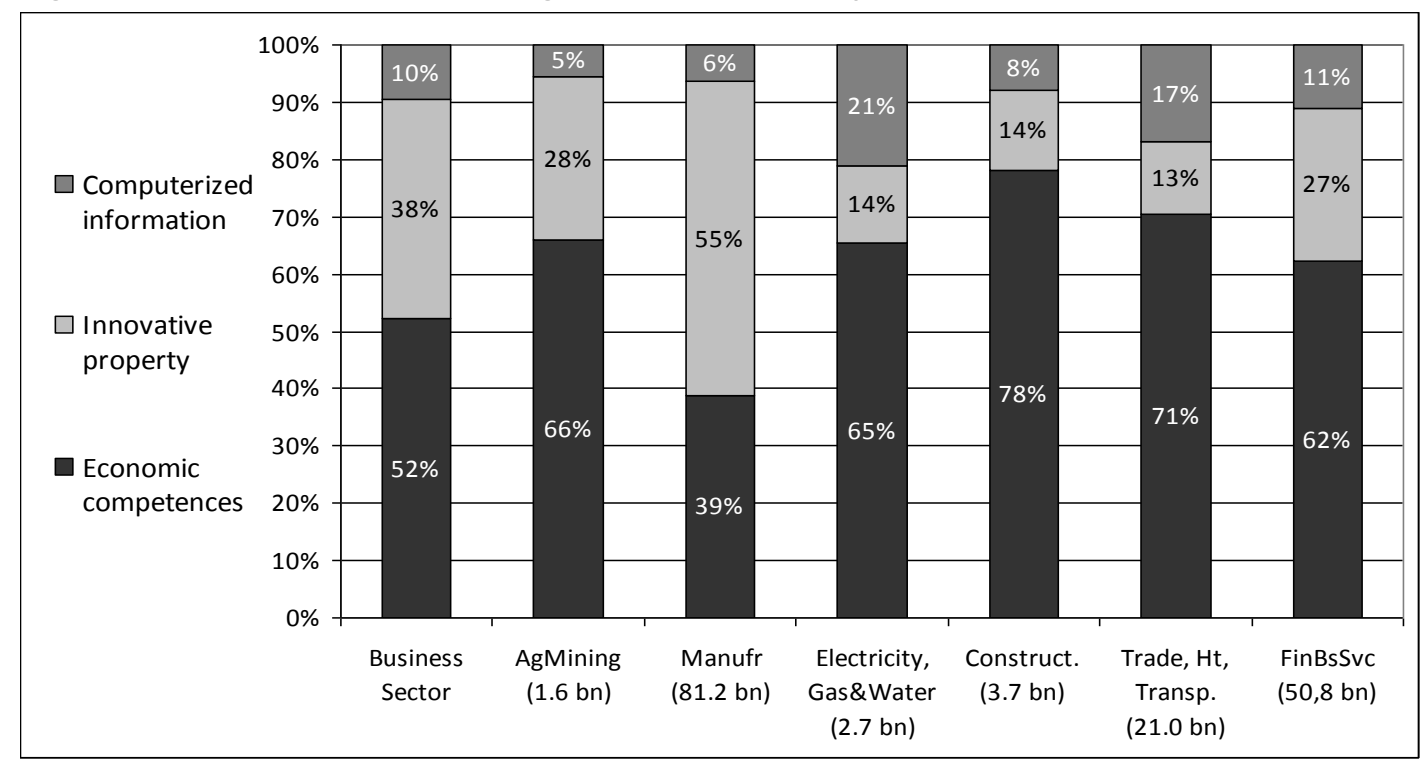

Sources: See Table 9; own calculation. 
This section is aimed at comparing intangible investment with tangible investment in German industries. Over the period 1995-2006, that is the period for which we have complete data, investment in intangible capital has grown from $138.6 \mathrm{bn} €$ to $180 \mathrm{bn} €$ in the German business sector. This implies an increase by $30 \%$ (see Figure $3-1$ ). This raise was disproportionately high in computerized information and innovative property. The figure also suggests that investment in intangibles react to business cycles. The increase was particularly strong in the boom period 1998-2000 whereas firms have cut investments in the recession period 2001-2004 by nearly 5\%. However, with the slight recovery from 2005 onwards, investments in intangibles have accelerated again. The figure furthermore shows a stable distribution across industries over time. Nearly half of the investment in intangibles is done by manufacturing firms. This industry proportion is much higher than the share of manufacturing in gross output, value added or for instance in labour input. Financial and business services account for about one third of all intangible investments.

Figure 6: Investment in intangible assets by sector, 1995-2006

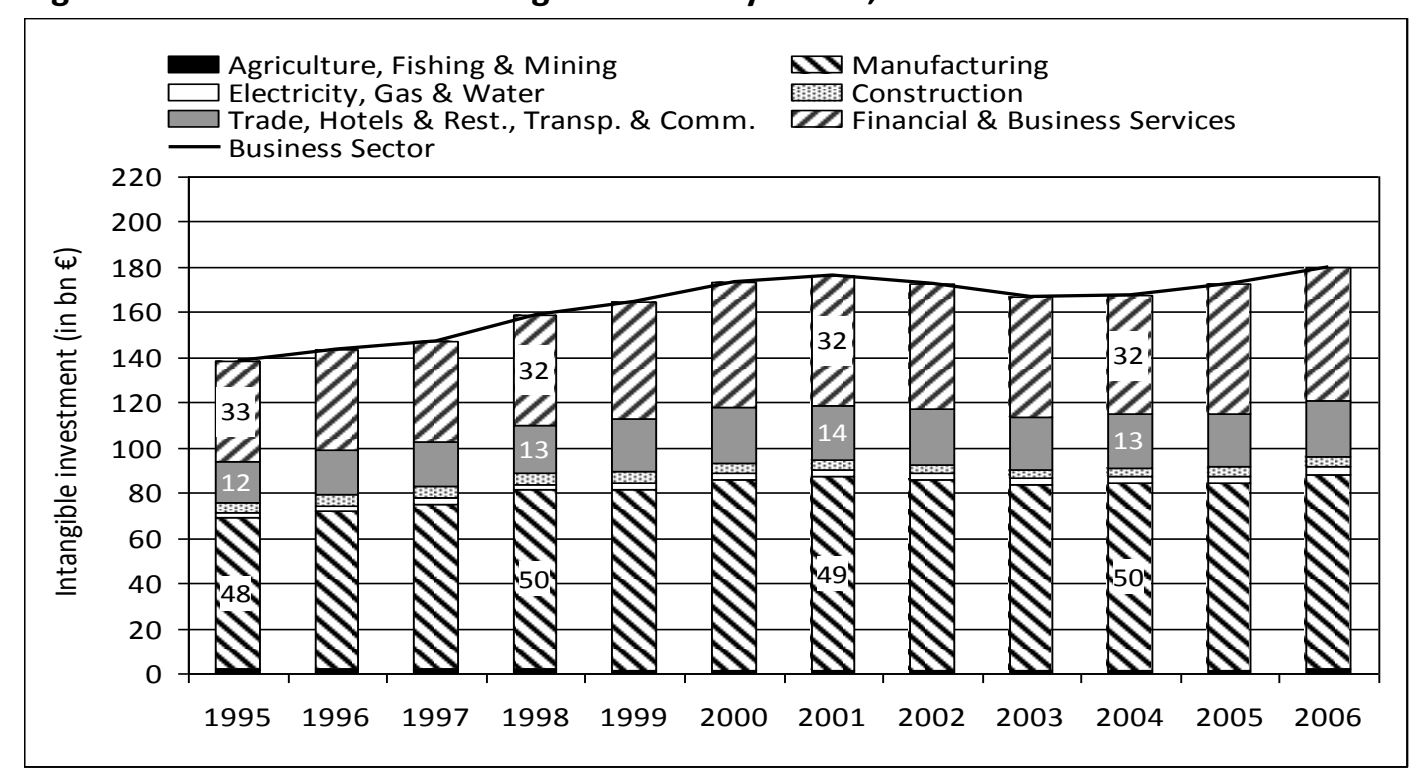

Sources: See Table 9; own calculation.

These figures can be directly compared to the development of tangible investment in Figure 7. Tangible investment is defined as the nominal gross fixed capital formation provided by EU KLEMS. It comprises investments in computing equipment, communications equipment, transport equipment, other machinery and equipment, and total non-residential investment in the business sector (but without software). Tangible investment has also increased over the period ( $+15 \%)$ but to a far lesser extent than intangible investment. On the other hand, tangible investment were also cut in the recession period and even more so than intangible investments (-15\% between 2000 and 2003). Tangible investment had started to increase again from 2004 onwards but had not reached the 2000 level in 2006. Compared to intangible investments we see more variation in the industry shares over time. In 1995, $27 \%$ of investment in tangible capital was allotted to manufacturing. This proportion has fallen to $25 \%$. Similarly, the contributions of utility, construction and agriculture and mining have declined. In contrast, financial and business services have gained importance ( 29 to $36 \%$ ). 
Figure 8 illustrates the relation between intangible and tangible investment at the sector level. Differences in the dynamics of both types of investment over time find expression in an increasing relation of intangible to tangible investment. For the whole business sector, the proportion has increased from $80 \%$ to $89 \%$. The figures further highlight the outstanding position of intangible capital in manufacturing where intangible investment is significantly larger than tangible investment. Intangible investment has even gained importance as it share has climbed from $138 \%$ to $168 \%$. Though firms in the financial and business service sector have expanded their investment for intangible capital, the importance relative to tangible capital is nearly unaltered. It fluctuates around $80 \%$ over the period. In the sector trade \& transport, intangible investments have grown faster than tangible investments leading to a rise in the proportion from 40 to $58 \%$. It turns out that this was a short-term effect and that this proportion has fallen again to $45 \%$. Rather surprising is the development of the ratio of intangible to tangible investment in construction. It has increased from $67 \%$ to $151 \%$. This can be explained by a sharp decline in tangible investment figures reported by EU KLEMS (from 6.8 to 2.9 bn $€$ ) whereas the intangible investment turned out to be stable at 3-4 bn € each year.

\section{Figure 7: Tangible investment by sector, 1995-2006}

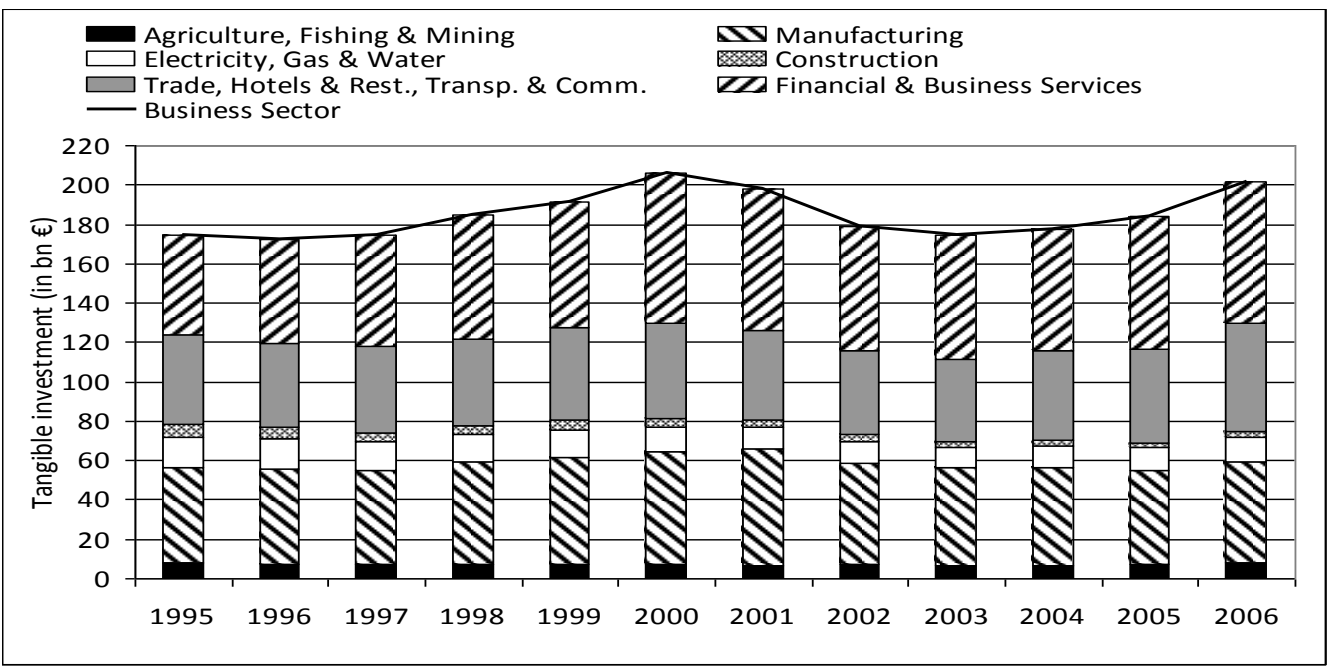

Source: EU KLEMS Nov2009 Release; own calculation.

Figure 8: Share of intangible to tangible investments by sector, 1995-2006

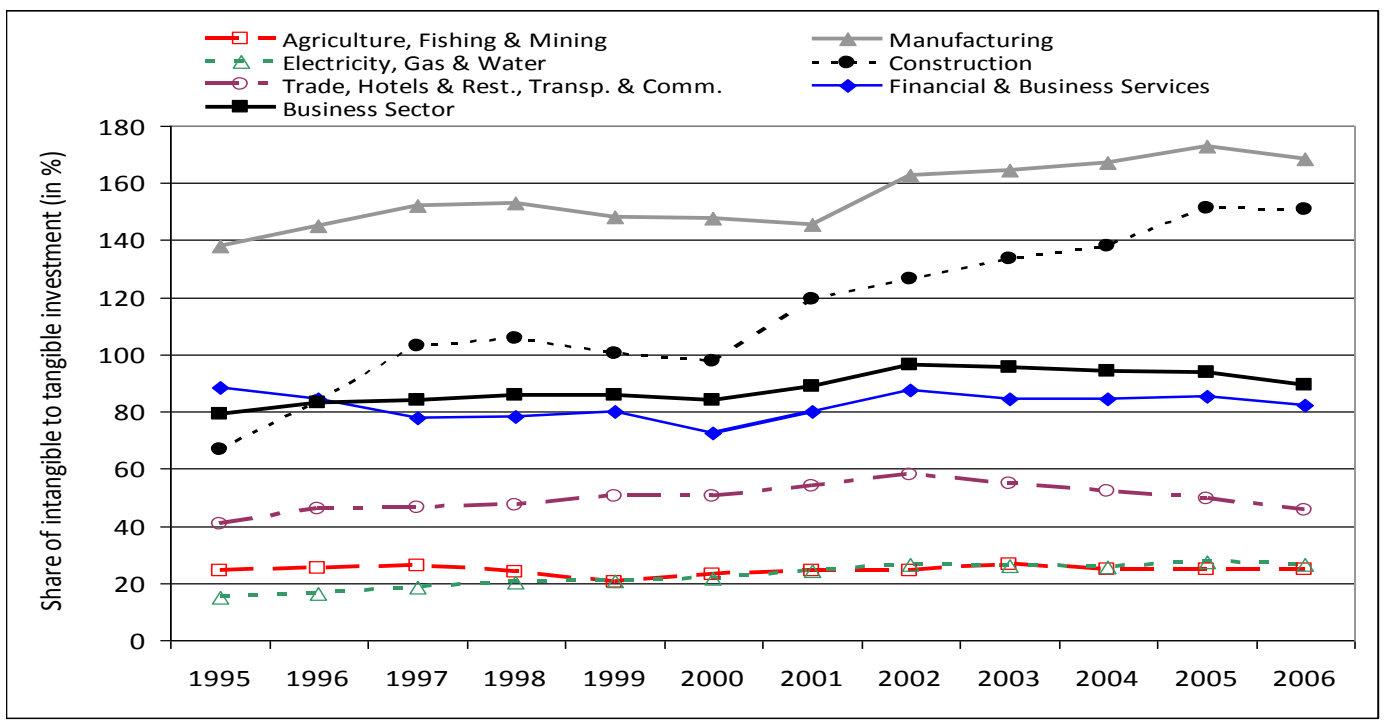

Source: Intangible investment: see Table 9, tangible investment: EU KLEMS Nov2009 Release; own calculation. 
The previous sections have shown that investments in intangibles have increased in absolute terms and have also gained importance compared to tangible capital. Figure 9, however, reveals that the share of intangible investment in gross output has fallen in the two largest sectors, manufacturing and financial and business services. In the latter industry, which spends the highest proportion on intangible investment throughout the whole period, it has declined from 9.1 to $8.1 \%$. A similar downward trend is observed in manufacturing where the share dropped from 6.7 to $5.6 \%$. A similar picture emerges for financial and business services when we relate intangible investment to value added (from 14.3 to 13.4\%), see Figure 10. In manufacturing, the share of intangible investment to value added has increased until 1998 and has fallen afterwards. In 2006 it has reached a comparable level than in 1995 (15\%). In terms of gross output, financial and business services spend the highest proportion on intangible investment. In terms of value added manufacturing is ranked first. In the other four sectors intangible investments make up a significantly smaller proportion of gross output. It varies around $2 \%$ (construction), 3\% (agriculture \& mining) and 3.5\% (trade \& transport, utility). The same holds for the share in value added which ranges between 4 and $7.5 \%$ for the four sectors.

Figure 9: Intangible investment as a share of industry gross output, 1995-2006

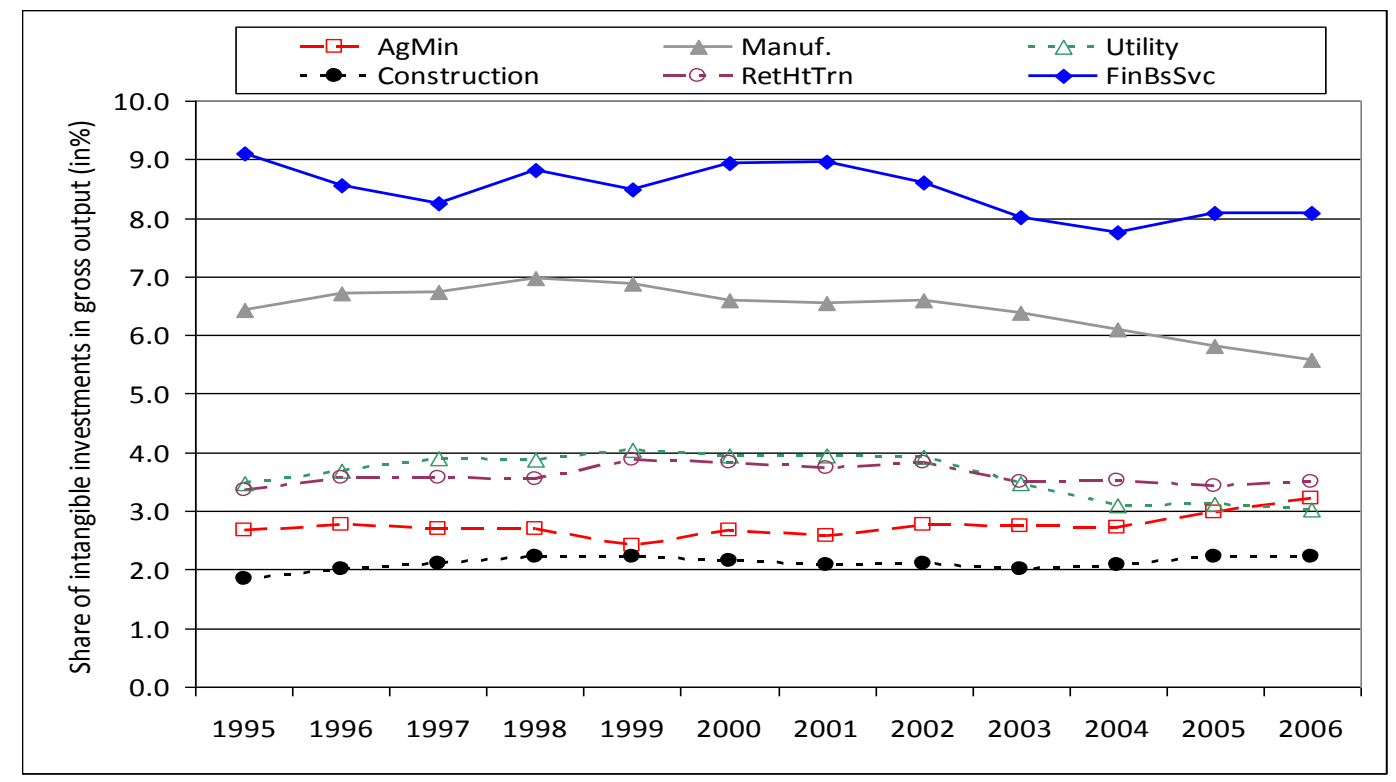

Source: Intangible investment: see Table 9, gross output: EU KLEMS Nov2009 Release; own calculation. 
Figure 10: Intangible investment as a share of industry value added, 1995-2006

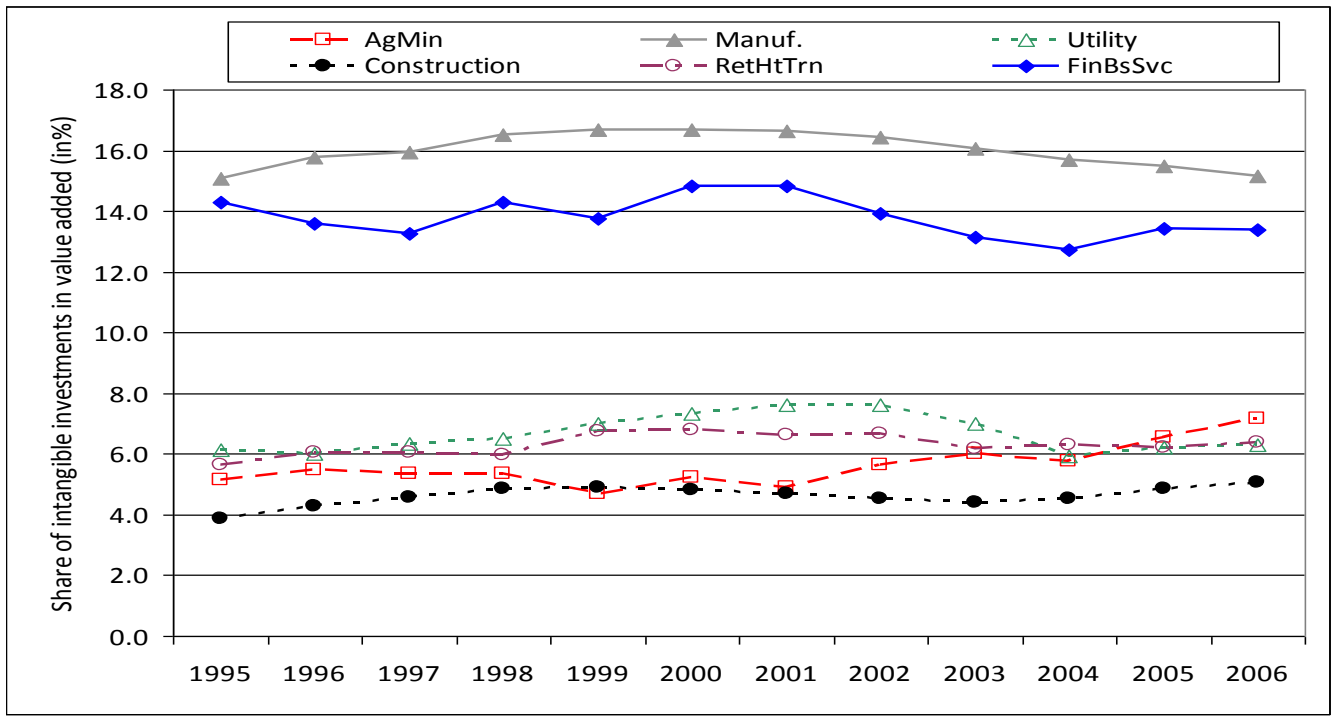

Source: Intangible investment: see Table 9, value added: EU KLEMS Nov2009 Release; own calculation.

\section{Comparing intangible investment at the sector level in Germany and the UK}

To evaluate intangible investments in German sectors, we compare figures with industry-level findings for another large European country, the UK (see Gil and Haskel 2008). ${ }^{6}$ Before showing sector-level results, we first present total investment in intangibles by asset class in 2004 as a share of the gross output. Figure 11 reveals salient differences at the macro level for both countries. Investment in intangibles represents $7 \%$ of gross output in the UK (10.1\% of GDP, Marrano and Haskel, 2006). The share is thus significantly higher than in Germany with $5.1 \%$ (7.0 \% of GDP, Crass et al., 2010). On the other hand, the business sector in Germany invests twice as much as the UK in R\&D (1.2\% compared to $0.55 \%)$. In contrast, the UK invests a significantly larger proportion in software, design, firm-specific training and own-account organizational structure.

How can these differences be explained? Methodological differences might be one explanation. For some asset categories a trade-off exists between more accurate data sources and international comparability (see Crass et al. 2010). Deviations exist for instance with respect to new architectural and engineering designs. The UK figure does not only include purchased designs but also own-account investment in new architectural and engineering designs (Gil and Haskel, 2008). If we exclude ownaccount investments, the findings are much more similar across both countries $(0.94 \%$ in the UK and 0.87 in Germany). An alternative data source and methodology was also used for new product development costs in the financial industry. While our figures rely on survey data, the UK figures are estimated as 20 percent of financial services industry's intermediate purchases (Gil and Haskel 2008). The same is true for intangible investments in firm-specific human capital.

\footnotetext{
${ }^{6}$ In order to ensure comparability of intangibles we follow Marrano and Haskel (2006) and calculate UK investment figures by assuming that $60 \%$ and $80 \%$ of expenditures on advertising and own-account organizational structure are investment, respectively. Investment in new architectural and engineering designs is calculated using the authors' instruction to multiply expenditure by 50 percent to obtain investment (Gil and Haskel 2008).
} 
Figure 11: Intangible investment as share of gross output in Germany and the UK, by category in 2004

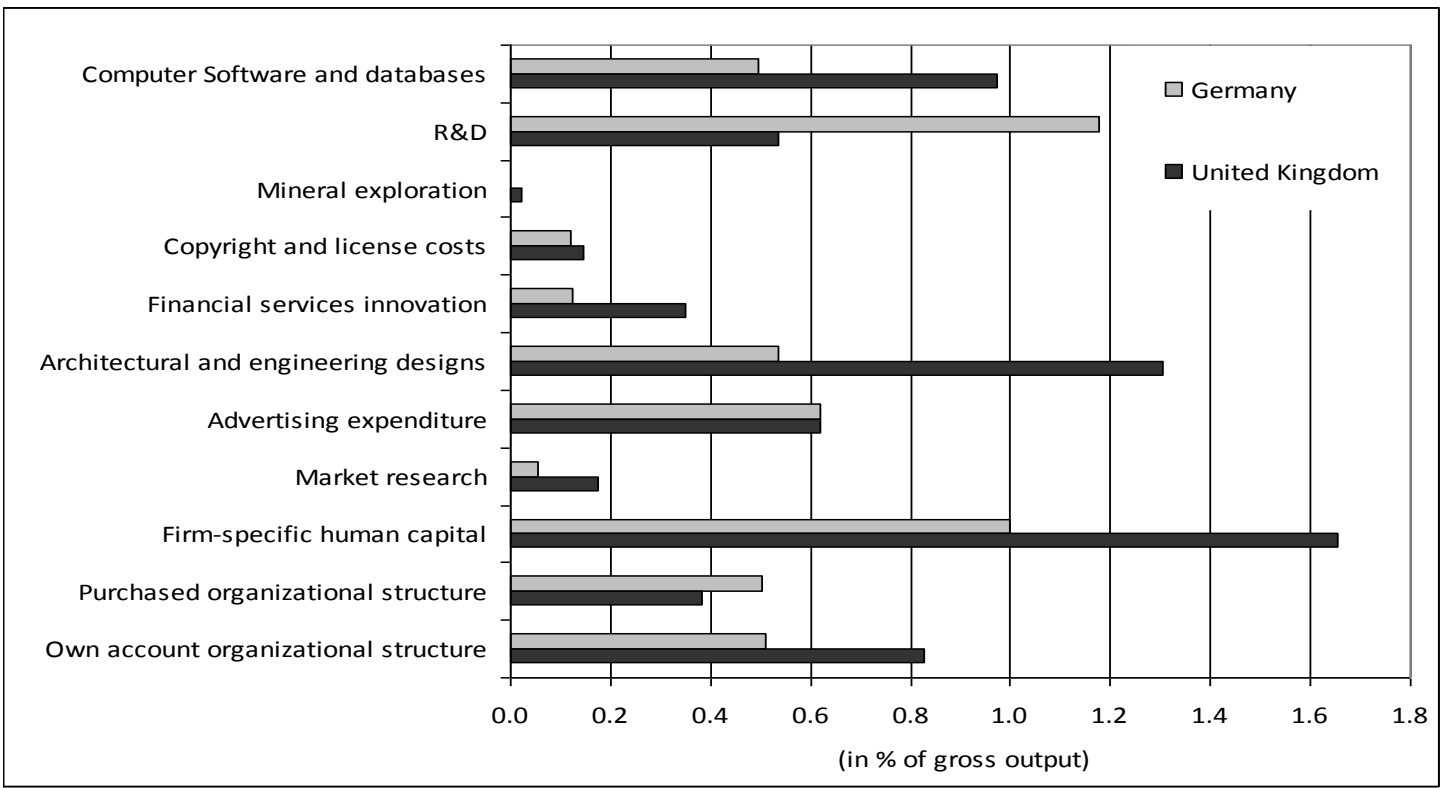

Source: Germany: see Table 9, UK: Gil and Haskel (2008); own calculation.

On the other hand, in all four categories service sectors make up an import contribution. Since services present a larger proportion in the UK business sector than in Germany, these differences might also be explained by differences in industry structure. A comparison of investment in intangibles at the sector level provides information about this. Except for utility, Table 2 shows that the UK share of intangible investment is larger in all sectors. When comparing manufacturing firms, we can ascertain that German firms invest a higher proportion of gross output in R\&D ( $2.6 \%$ vs. $2.0 \%)$ and in advertising ( 0.6 vs. $0.5 \%$ ). UK manufacturing firms, on the other hand, have a significantly stronger orientation towards investment in new designs. But they also invest a higher proportion of gross output in software, organizational structure, firm-specific human capital and copyright and licence cost. Similar differences in investment strategies can be detected in financial and business services. The proportion German firms invest in R\&D is four times larger than that in the UK. In contrast to manufacturing, they also invest a significantly larger proportion of gross output in purchased organizational structure. UK firms in financial and business services outperform their German counterpart with respect to investments in software, design, firm-specific human capital, market research, own-account organizational structure and financial service innovations. Another striking finding is that UK firms in trade \& transport demonstrate a higher share in all asset classes.

Comparing different asset classes, we find that investment in new architectural and engineering design is consistently higher across all sectors in the UK. Computerized information is around two times larger in UK manufacturing, financial and business services and trade \& transport (similar shares in other three sectors). On the other hand, German firms invest a higher proportion of gross output in R\&D in all sectors. Advertising is also more common in Germany except for the sector trade \& transport. 
Table 2: Intangible investment in Germany and the UK as share of gross output and by sector in 2004

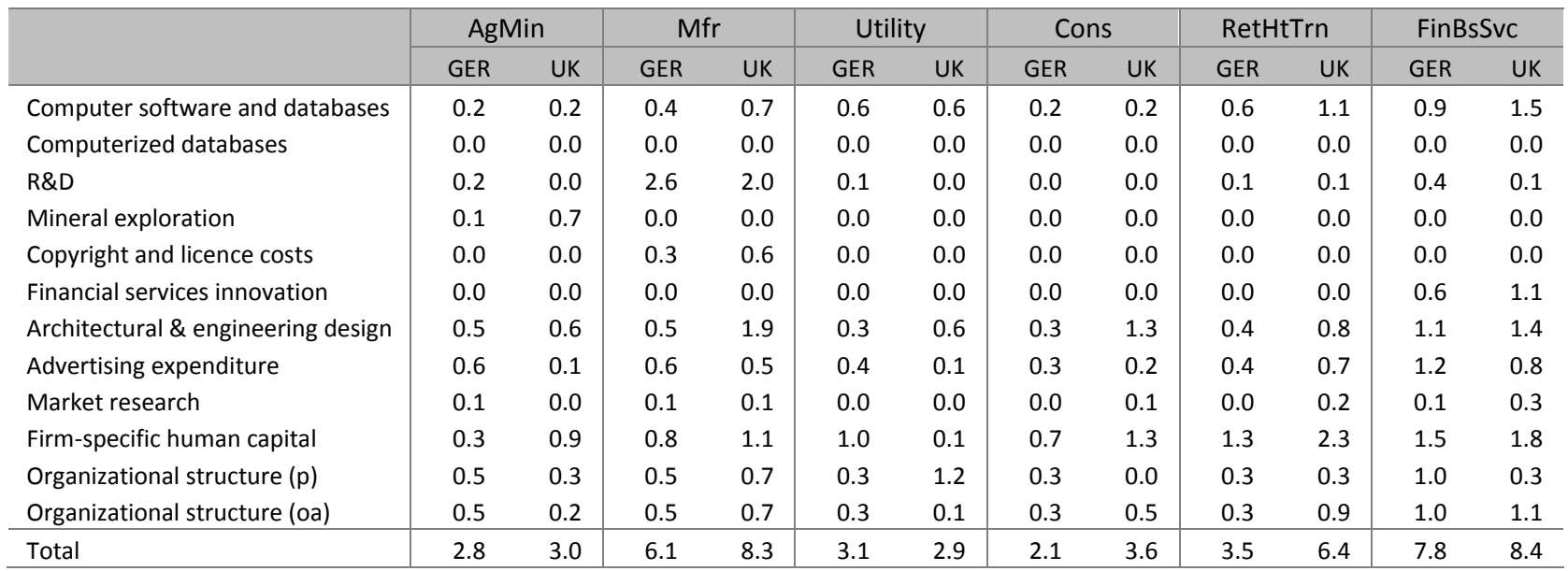

Source: Germany: see Table 9, UK: Gil and Haskel (2008); own calculation.

\section{Contribution of intangible assets for growth at the sector level}

This section highlights the contribution of intangible assets for stimulating growth at the sector level by performing growth accounting analyses for the six industries. The methodology we used to perform growth accounting at the sector level is based on the 'direct aggregation across industries' approach that is described by Jorgenson et al. (1987) and Jorgenson et al. $(2005,2007)$ and that is also used in Clayton et al. (2009). This approach allows us to study industry-level sources of economic growth as well as to trace the sources of aggregate productivity growth and input factor growth to their industry origins. In the following section 6.1, we will explore the methodology in more detail. Section 6.2 sets out the data that we used to perform growth accounting and section 6.3 illustrates our empirical results.

\subsection{Methodology}

\section{Decomposition of growth in real gross output at the industry level}

Assuming that we have production data at the sector level, the starting point is the decomposition of industry growth. At the industry level, growth in capital, labour, intermediate inputs and total factor productivity contributes to growth in real gross output $\left(\Delta \ln Y_{j}\right)$. The growth contribution of capital is equal to the growth in capital services in industry $j\left(\Delta \ln K_{j}\right)$ weighted by the capital input share $\left(\bar{v}_{K, j}\right)$. Capital services are defined as the productive inputs, per period, that flow to production from a capital asset (OECD 2001). Capital services differ from capital stocks because short-lived assets such as equipment and software provide more services per unit of stock than long-lived assets such as land. The flow of capital services is more appropriate as capital input in the production analysis than the capital stock (Jorgenson and Griliches 1967). The capital input share $\bar{v}_{K, j}$ is defined as the average (over a twoyear period) proportion of capital compensation to gross output in industry $j$. Similarly, the contribution of labour can be calculated as the growth in labour quality services $\left(\Delta \ln L_{j}\right)$ times the labour input share $\left(\bar{v}_{L, j}\right)$ which is measured as the average labour compensation in gross output in industry $j$. The contribution of intermediate inputs to growth in industry gross output is given by $\bar{v}_{X, j} \cdot \Delta \ln X_{j}$ where 
$\Delta \ln X_{j}$ measures the growth rate in intermediate inputs and $\bar{v}_{X, j}$ is the share of intermediate inputs in industry gross output. ${ }^{7}$ The contribution of total factor productivity is simply the growth rate of TFP ( $\left.\Delta \ln T F P_{j}\right)$. That is, we can decompose growth in industry real gross output into the following sources:

$$
\Delta \ln Y_{j}=\bar{v}_{K, j} \cdot \Delta \ln K_{j}+\bar{v}_{L, j} \cdot \Delta \ln L_{j}+\bar{v}_{X, j} \cdot \Delta \ln X_{j}+\Delta \ln T F P_{j}
$$

In the empirical analysis below, we furthermore allow for heterogeneous labour and capital. That is, we differentiate between different types of capital assets and labour inputs. With respect to capital we separately calculate the contribution of tangible and intangible capital. We furthermore decompose tangible capital into ICT capital and non-ICT capital. Types of intangible capital assets correspond to the categories introduced in section 2 . The question is then how to measure capital services. Under the assumption of a strict proportionality between capital services and capital stocks for each heterogeneous asset, the growth of total capital services in industry $\mathrm{j}\left(\Delta \ln K_{j}\right)$ can be calculated as a translog index (i.e. a Tornqvist index) of different types of capital assets (see Jorgenson 1963, and Jorgenson and Griliches, 1967). That is, $\Delta \ln K_{j}$ is a weighted average of the growth rates of each capital stock $\Delta \ln K_{k, j}^{S t}$, where the superscript $S t$ indicates that we mean the capital stock and $k$ denotes the type of capital:

$$
\Delta \ln K_{j}=\sum_{k} \bar{w}_{k, j} \cdot \Delta \ln K_{k, j}^{S t}
$$

The weight $\bar{w}_{k, j}$ reflects the proportion of capital income of asset $k$ in total capital income in industry $j$, averaged over a two-year period. Capital income of asset $k$ is usually calculated as the capital stock of asset $k$ times the rental price of capital $k$ (user costs of capital).

Accordingly, growth in labour services in industry $j$ are estimated as a labour-income weighted average of the growth rates of each type of labour input $l$ :

$$
\Delta \ln L_{j}=\sum_{l} \bar{w}_{l, j} \cdot \Delta \ln L_{l, j}
$$

\section{Decomposition of real value added growth at the industry level}

Since at the aggregate level, output growth is usually based on growth in value added instead of growth in gross output, we additionally provide the decomposition of industry value added growth. Using the definition of value added, we can also write equation (1) in the following way:

$$
\Delta \ln Y_{j}=\bar{v}_{V A, j} \cdot \Delta \ln V A_{j}+\bar{v}_{X, j} \cdot \Delta \ln X_{j}
$$

Equation (4) states that industry growth in gross output can be decomposed into the contribution of value added and intermediate goods. $\bar{v}_{V A, j}$ denotes the two-year average share of value added in gross output in industry j. Equalizing equation (1) and (4), we can identify the sources of real value added growth in industry j:

\footnotetext{
${ }^{7} \bar{v}_{X, j}$ is equal to $1-\bar{v}_{L, j}-\bar{v}_{K, j}$.
} 


$$
\Delta \ln V A_{j}=\frac{\bar{v}_{K, j}}{\bar{v}_{V A, j}} \cdot \Delta \ln K_{j}+\frac{\bar{v}_{L, j}}{\bar{v}_{V A, j}} \cdot \Delta \ln L_{j}+\frac{1}{\bar{v}_{V A, j}} \Delta \ln T F P_{j}
$$

Growth in real value added in industry $\mathrm{j}$ is fed by the weighted contribution of industry capital, labour input and TFP. The weights on capital (labour) account for the share of capital (labour) income in gross output in industry $\mathrm{j}$ and for (the inverse of) the share of industry value added in industry gross output.

\section{Aggregate real value added growth and industry contributions}

Depending on the assumptions about industry value added functions and factor mobility and factor prices, one yields alternative measures for aggregate value added. We use the 'direct aggregation across industries' approach that is the least restrictive approach. This approach only assumes that a value added function exists in each industry, but it does not assume that these are identical across industries. We furthermore allow input factors such as capital and labour to be mobile across industries and factor prices to be different across industries. ${ }^{8}$ It can be shown that in this case, the growth rate in aggregate real value added $(\triangle \ln V A)$ has to be calculated as the weighted sum of industry real value added growth rates:

$$
\Delta \ln V A=\sum_{j} \bar{w}_{j} \cdot \Delta \ln V A_{j}=\sum_{j} C T_{V A, j}
$$

$C T_{V A, j}=\bar{w}_{j} \cdot \Delta \ln V A_{j}$ measures what industry j contributes (CT) to aggregate real value added growth. Summing up all contributions across industries gives the aggregate growth rate. The weight $w_{j}$ reflects the share of industry $j^{\prime}$ 's nominal value added in aggregate nominal value added $^{9}$, and it is thus a measure of the relative size of industry $\mathrm{j} . \bar{w}_{j}$ is average share of a two-year period, that is:

$$
w_{j}=\frac{P_{V A, j} \cdot V A_{j}}{\sum_{j} P_{V A, j} \cdot V A_{j}} \quad \text { and } \quad \bar{w}_{j}=0.5\left(w_{j, t}-w_{j, t-1}\right)
$$

\section{Decomposition of real value added growth at the aggregate level}

The methodology not only allows us to identify the industry origins of aggregate growth but also to identify what change in aggregate growth is due to capital input, labour input and TFP. Inserting equation (5) into (6), we end up with the following decomposition of real value added growth:

\footnotetext{
8 Alternatives are the aggregate production function approach and the production possibility frontier approach. The first approach assumes the existence of an aggregate production function. This function exists under the strong assumptions that i) the industry gross output function is separable in value added (VA) and intermediate inputs; ii) the VA functions are - up to a scalar multiplier - identical across industries; iii) the functions that aggregate heterogeneous capital and labour are identical in all industries and iv) that each type of capital and labour must have the same factor price in all industries. If these assumptions are fulfilled, aggregate VA is the unweighted sum of industry VA. The second approach relaxes the restriction that the industry VA functions must be the same across industries. Aggregate VA is then a weighted sum of industry VA.

${ }^{9}$ See Table 1. Two-year averages of these industry shares in values added serve as weights for summing up the growth rates of industry value added.
} 


$$
\begin{aligned}
& \Delta \ln V A=\sum_{j} \bar{w}_{j} \cdot\left(\frac{\bar{v}_{K, j}}{\bar{v}_{V A, j}} \cdot \Delta \ln K_{j}+\frac{\bar{v}_{L, j}}{\bar{v}_{V A, j}} \cdot \Delta \ln L_{j}+\frac{1}{\bar{v}_{V A, j}} \Delta \ln T F P_{j}\right) \\
& \Delta \ln V A=\sum_{j} \bar{w}_{j} \cdot \frac{\bar{v}_{K, j}}{\bar{v}_{V A, j}} \cdot \Delta \ln K_{j}+\sum_{j} \bar{w}_{j} \cdot \frac{\bar{v}_{L, j}}{\bar{v}_{V A, j}} \cdot \Delta \ln L_{j}+\sum_{j} \bar{w}_{j} \cdot \frac{1}{\bar{v}_{V A, j}} \Delta \ln T F P_{j} \\
& \Delta \ln V A=\sum_{j} C T_{K, j}+\sum_{j} C T_{L, j}+\sum_{j} C T_{T F P, j}
\end{aligned}
$$

$\Delta \ln V A=C T_{K}+C T_{L}+C T_{T F P}$

The last equation illustrates the decomposition of aggregate value added growth. It can be traced back to the contribution of capital input $\left(C T_{K}\right)$, labour input $\left(C T_{L}\right)$ and TFP $\left(C T_{T F P}\right)$. The total contribution of capital input $\left(C T_{K}\right)$ is the sum of the industry contributions of capital input across all industries. To put it differently, $C T_{K, j}$ measures what industry $\mathrm{j}$ contributes to aggregate capital input. It is calculated as the growth of capital services in industry $j$ weighted by the average capital compensation to gross output in industry $j$, the average proportion of gross output to value added in industry $j$ and the relative size of industry j's value added in aggregate value added. Similarly, $C T_{L, j}$ and $C T_{T F P, j}$ show how much each industry contributed to aggregate labour input and aggregate TFP.

\subsection{Industry data}

In order to perform an industry growth decomposition that accounts for intangible capital, we need production data at the sector level. We make use of EU KLEMS output data that provides information on gross output, value added and intermediate inputs, both in real and nominal values as well as corresponding price deflators. Intermediate inputs consist of material, energy and services. Data are available from 1970 onwards, but since we have complete data on intangibles only for the period from 1995 to 2006, we are restricted to this period.

EU KLEMS capital data also allow us to account for heterogeneous capital and labour. It provides time series on nominal investment (nominal gross fixed capital formation), differentiated by the following types of capital: computing equipment (IT), communications equipment (CMT), software (SOFT), transport equipment (TraEq), other machinery and equipment (oMach) and non-residential investment (oCon). ${ }^{10}$ From the list it follows that the term capital that is already accounted for in EU KLEMS numbers on gross output and value added is a combination of mostly tangible capital and one category of intangible capital (software). The use of disaggregate capital time series, however, allows us to strictly define tangible capital (IT, CMT, TraEq, oMach, oCon) and intangible capital (software plus the other categories explored in section 2 ) and to modify numbers on aggregate gross output or value added, once when we only incorporate tangible capital and in a second version in which we account for all types of intangible capital. EU KLEMS data also deliver price deflators and nominal and real capital stocks for each type of asset (IT, CMT, SOFT, TraEq, oMach, oCon) and it provides time-constant

10 We do not take into account investments in residential structures. 
estimates of (geometric) depreciation rates for each capital asset. In most cases the depreciation rate for one asset is constant across industries. In some cases, however, the rates differ across industries. For industries 1, 5 and 6 we then use an average rate (see Table 9-9). In order to build intangible capital stocks, we use investment data for each type of intangible assets and employ the perpetual inventory method. The underlying depreciation rates are also set out in Table 17 (see Corrado et al. 2009). As price deflator, we use the implicit value added deflator for each type of intangible asset.

Basic data on capital income at the sector level, needed for calculating weights in the growth accounting analysis, is also taken from EU KLEMS capital data. It publishes capital compensation by type of asset k= IT, CMT, TraEq, oMach, oCon, SOFT. We use the sum of capital compensation for assets k= IT, CMT, TraEq, oMach, oCon as a measure for capital income of tangible capital.

One problem that we are confronted with is the fact that we neither do observe capital compensation for intangible capital in total nor for each type of intangible asset. Hence, we also lack information on total capital income. To solve this problem, we employ the following procedure. Starting point is the fact that capital compensation of asset $\mathrm{k}$ can be calculated as its rental price times the capital stock. The rental price or user cost of capital consists of the nominal rate of return ror $_{k}$ (reflecting the opportunity cost of holding the asset $k$ ) plus the nominal cost of depreciation for asset $k$ and minus the nominal gain from holding the asset for each accounting period, i.e. the capital gain (see Azeez Erumban, 2008). For each capital asset, we already possess information on capital stocks and depreciation rates. We furthermore estimate capital gains for each asset by using a three-year moving average of the change in capital prices. However, what about the rate of return? In order to get an estimate of the rate of return, we use the suggestion by Hall and Jorgenson (1967). That is, we assume that the rate of return is unknown but constant across all assets $\left(\right.$ ror $_{k}=$ ror $)$. Under this assumption, we can estimate the common rate of return as the total capital income minus the sum of depreciation costs over all assets plus the sum of capital gains for all assets and finally divided by the total nominal capital stock. Having an estimate for the rate of return of asset $\mathrm{k}\left(\mathrm{ror}_{k}=r o r\right)$, we can then use the above formula to estimate the rental price of each asset $\mathrm{k}$ and subsequently the capital income for each type of capital. Note that we have two estimates of the rate of return ( ror ). In version one, we assume that total capital income equals the capital compensation for tangible capital. In version two, in which we account for intangible assets, total capital income is estimated as the income for tangible capital plus the sum of investments for intangible capital as an estimate for the compensation of intangible capital. ${ }^{11}$

Finally, in order to measure the growth of total labour services and the growth in labour services per hour worked, we extract data on total labour costs and total hours worked from EU KLEMS output data (November 2009 release). The EU KLEMS March 2008 release provides time series on heterogeneous labour input, i.e. labour compensation and hours worked for 18 different groups of labour. Employees and self-employed persons are differentiated according to their educational degree (high-, medium- and low-skilled), gender and their age (below 29, 30-49 and above 50). ${ }^{12}$

\footnotetext{
11 The average rate of return in version one is 0.083 and in version two 0.086 . Both are highly correlated indicated by a correlation coefficient of about 0.986 .

12 This type of information is only available until 2005. The missing observations for 2006 are estimated based on the total labour compensation for 2006 and the share of labour compensation for each group in 2005.
} 
Complete data for all time series are available for the years 1995-2006. Since we take a two-year period average for the weights and measure capital gains within the rate of return calculation as a three-year moving average of changes in capital prices, we lose observations and can only use the period 19972006 for the growth accounting. That is, the first growth rate measures changes in labour productivity between 1996 and 1997.

\subsection{Growth accounting results}

This section delineates the sources of economic growth at the sector level, at the aggregate level and the industry contributions to economic growth and capital and labour input.

\section{Decomposition of growth in real gross output at the industry level}

We start with the decomposition of growth in real gross output at the industry level (equation (1), in combination with (2) and (3) to account for heterogeneous inputs). The upper panel of Table 3 describes a situation in which the growth accounting framework only includes tangible capital (assets $k=I T, C M T$, TraEq, oMach, oCon). In the second panel, we additionally account for intangible capital. The first row depicts the growth rate in gross output across industries. Over the period 1997 to 2006, gross output increased on average by roughly $2.3 \%$ to $3.2 \%$ per year in four out of six industries while it declined in agriculture \& mining $(-0.4 \%)$ and construction $(-2.7 \%)$. At the same time, labour input intensity has changed. That is, the number of hours worked has been reduced in most industries, except in financial and business services where we observe an average annual increase of around $3.7 \%$. When we take both developments together, we get the change in labour productivity (in terms of gross output). The average annual growth rate in labour productivity was highest in utility at about $6.4 \%$, but likewise high in manufacturing $(+4.6 \%)$. In agriculture \& mining and trade \& transportation, the figures indicate a moderate growth in labour productivity of about $2.4 \%$ and $2.6 \%$, respectively. Labour productivity has even been slightly slowed down in the remaining two German industries.

The decomposition of the sources of growth between primary inputs and TFP emphasizes that intermediate inputs contributed the most to labour productivity growth in all sectors in Germany, except in financial and business services. This pattern emerges in both panels. Looking at the lower panel, the intermediate input deepening accounts for a raise of labour productivity of about 3.9 percentage points in utility. In manufacturing, growth in intermediate inputs led to a 3.1 percentage point increase in labour productivity which is nearly $73 \%$ of the overall increase in manufacturing. The contribution of intermediate inputs to growth is much smaller in absolute terms in the sectors agriculture $\&$ mining and trade \& transport where this figure is roughly 1 percentage point. In construction intermediate inputs contributed only a negligible amount to labour productivity growth and in financial services, this effect was even negative.

A second striking result is that growth in labour quality contributed only to a very limited extent to industry growth in labour productivity. In both panels, the contribution never exceeds 0.08 percentage points and is even slightly negative for three out of six industries (agriculture \& mining and both service sectors). Results for the UK have shown a much higher absolute and relative contribution of labour input to labour productivity, in particular for manufacturing and both service sectors (contribution varies between 0.2 and 0.3 percentage points with a smaller labour productivity growth at the same time; see Clayton et al., 2009). 
Table 3: $\quad$ Contributions of different types of intangible assets to labour productivity growth (in terms of gross output) by sector, 1997-2006

\begin{tabular}{|c|c|c|c|c|c|c|}
\hline & AgMin & Mfr. & Utility & Cons. & RetHtTm & FinBsSvc \\
\hline & \multicolumn{6}{|c|}{ Excluding intangibles } \\
\hline Gross output & -0.44 & 2.94 & 2.69 & -2.66 & 2.33 & 3.15 \\
\hline Hours worked & -3.00 & -1.65 & -3.69 & -2.37 & -0.02 & 3.66 \\
\hline Labour productivity & 2.56 & 4.59 & 6.38 & -0.29 & 2.35 & -0.51 \\
\hline Capital deepening & -0.06 & 0.21 & 1.44 & -0.03 & 0.33 & 0.44 \\
\hline ICT capital & 0.02 & 0.04 & 0.09 & 0.02 & 0.11 & 0.39 \\
\hline Non-ICT capital & -0.08 & 0.17 & 1.35 & -0.05 & 0.22 & 0.05 \\
\hline Intangible capital & - & - & - & - & - & - \\
\hline Labour quality & -0.22 & 0.07 & 0.04 & 0.08 & -0.01 & -0.03 \\
\hline Intermediate input deepening & 1.21 & 3.34 & 4.07 & 0.09 & 1.21 & -0.22 \\
\hline \multirow{2}{*}{ TFP } & 1.62 & 0.97 & 0.83 & -0.43 & 0.81 & -0.70 \\
\hline & \multicolumn{6}{|c|}{ Including intangibles } \\
\hline Gross output & -0.45 & 2.91 & 2.72 & -2.65 & 2.34 & 3.20 \\
\hline Hours worked & -3.00 & -1.65 & -3.69 & -2.37 & -0.02 & 3.66 \\
\hline Labour productivity & 2.55 & 4.55 & 6.41 & -0.28 & 2.36 & -0.46 \\
\hline Capital deepening & 0.16 & 0.83 & 1.86 & 0.13 & 0.59 & 0.87 \\
\hline ICT capital & 0.02 & 0.04 & 0.09 & 0.02 & 0.12 & 0.39 \\
\hline Non-ICT capital & -0.06 & 0.20 & 1.39 & -0.05 & 0.23 & 0.06 \\
\hline Intangible capital & 0.20 & 0.59 & 0.38 & 0.17 & 0.23 & 0.42 \\
\hline Computerized information & 0.01 & 0.04 & 0.09 & 0.01 & 0.05 & 0.07 \\
\hline Software & 0.01 & 0.04 & 0.09 & 0.01 & 0.05 & 0.06 \\
\hline Databases & 0.00 & 0.00 & 0.00 & 0.00 & 0.00 & 0.00 \\
\hline Innovative property & 0.07 & 0.39 & 0.07 & 0.04 & 0.04 & 0.20 \\
\hline Scientific R\&D & 0.02 & 0.29 & 0.01 & 0.00 & 0.01 & 0.05 \\
\hline Mineral exploration & 0.01 & 0.00 & 0.00 & 0.00 & 0.00 & 0.00 \\
\hline Copyright licences & 0.00 & 0.04 & 0.00 & 0.00 & 0.00 & 0.00 \\
\hline Financial services innovation & 0.00 & 0.00 & 0.00 & 0.00 & 0.00 & 0.07 \\
\hline Architectural \& engineering design & 0.04 & 0.06 & 0.06 & 0.04 & 0.03 & 0.09 \\
\hline Economic competencies & 0.12 & 0.17 & 0.23 & 0.11 & 0.15 & 0.15 \\
\hline Advertising & 0.03 & 0.03 & 0.03 & 0.01 & 0.02 & 0.00 \\
\hline Market research & 0.00 & 0.00 & 0.00 & 0.00 & 0.00 & 0.00 \\
\hline Firm-specific human capital & 0.02 & 0.06 & 0.11 & 0.06 & 0.08 & 0.05 \\
\hline Organizational structure $(p)$ & 0.03 & 0.03 & 0.04 & 0.02 & 0.02 & 0.04 \\
\hline Organizational structure (oa) & 0.04 & 0.05 & 0.05 & 0.03 & 0.03 & 0.07 \\
\hline Labour quality & -0.22 & 0.07 & 0.04 & 0.08 & -0.01 & -0.03 \\
\hline Intermediate input deepening & 1.04 & 3.09 & 3.89 & 0.08 & 1.13 & -0.03 \\
\hline TFP & 1.57 & 0.56 & 0.62 & -0.57 & 0.66 & -1.26 \\
\hline
\end{tabular}

Notes: Reported are average annual percentages. Tangible capital includes ICT capital consisting of computing equipment and communications equipment, non-ICT capital consisting of transport equipment, other machinery and equipment and nonresidential investment. Intangible capital comprises software, databases, scientific R\&D, mineral exploration, copyright and licence costs, financial services innovation, purchased and own-account architectural and engineering design, advertising, market research, training and purchased and own account organizational structure. Data: See section 2 and 6.2.; own calculation.

When we only account for tangible capital, the contribution of capital to growth is also relatively small, except for utility (+1.4 percentage points). In manufacturing, capital deepening has induced an increase in labour productivity of about 0.2 percentage points. It is only slightly larger in the two service sectors and even slightly negative in remaining two sectors (agriculture \& mining, construction). The slow-down in growth in these two sectors can be traced back to a negative contribution of Non-ICT capital whereas ICT capital has stimulated growth in all industries. Another salient result pertains to the relative importance of ICT and non-ICT capital. Whereas non-ICT capital is much more important for generating growth in sectors such as manufacturing, trade \& transport and utility, ICT has a larger contribution in the other three sectors; in particular in financial business services where it raised annual average growth by 0.4 percentage points. 
When we include intangible capital, total capital deepening gets positive and larger in all industries. It then ranges between 0.13 percentage points in construction and 1.86 percentage points in utility, manufacturing being in between with an increase of about 0.9 percentage points. Growth in intangible assets has stimulated labour productivity growth in all sectors. The contribution varies between 0.17 (construction) and 0.59 (manufacturing) percentage points. Compared to the UK, however, intangible capital deepening seems to be somewhat smaller in absolute and relative terms in most sectors. For instance, it amounts to 0.97 percentage points in UK manufacturing (Clayton et al., 2009), but only 0.59 percentage points in Germany. Another outstanding result is the fact that the contribution of intangible capital in Germany was higher than that of ICT and non ICT capital separately in all German sectors, except for utility. In manufacturing, agriculture \& mining and construction, intangible capital deepening was even larger than tangible capital deepening.

Growth in TFP, defined as growth in output per unit of input, plays a major role in explaining industry growth in labour productivity. In manufacturing, growth in TFP boosts labour productivity growth by nearly 1 percentage point when we do not include intangible capital. This implies that roughly $21 \%$ of labour productivity growth in this sector cannot be explained by growth in capital, labour and intermediate inputs. In trade \& transport, TFP accounts for 0.8 percentage points increase in labour productivity which means $34 \%$ of overall labour productivity growth. The role of TFP is particularly strong in agriculture \& mining, which could be related to the fact that we do not account for factor input land. On the other hand, its contribution was negative in financial and business services and construction. The inclusion of intangible capital has led to a decline in the contribution of TFP in all sectors which implies that part of the effect of TFP in the upper panel was due to the fact that we missed intangible capital. Of course, the reduction in the contribution of TFP turns out to be particularly strong in those industries where growth in intangible capital revives labour productivity growth to a larger extent, i.e. in manufacturing, utility and financial \& business services. Accounting for intangible capital furthermore illustrates that (except for agriculture \&mining) manufacturing does not show the highest contribution of TFP growth any longer but that the effect of TFP growth is now larger in trade \& transport and utility.

Table 3 further disentangles the contribution of intangible capital into its different components. The results reveal that growth of innovative property capital is the most influential type of intangible capital for labour productivity in manufacturing and financial \& business services, followed by economic competencies and computerized information. In all other sectors, growth of intangible capital that measures economic competencies play the most prominent role for labour productivity growth, followed by innovative property capital and computerized information.

The contributions of innovative property capital show the highest variance across industries. They range from a 0.39 percentage points increase in labour productivity in manufacturing to a 0.04 percentage points increase in trade \& transport. Innovative property capital thus accounts for $65 \%$ of the total contribution of intangible capital in manufacturing. The lion's share $(0.29$ percentage points or a share of $49 \%$ ) can be allotted to the growth in scientific R\&D. In manufacturing, a rise in labour productivity of about 0.06 percentage points, which corresponds to a share of $9.6 \%$ of intangible capital deepening, is due to new architectural and engineering designs. The contribution of innovative property capital in manufacturing (0.39) is roughly twice as big as in the financial and business service sector (0.2). Growth in intangible capital based on new architectural and engineering designs is by far the most important source of growth ( 0.09 percentage points) among intangible assets in this sector, followed by financial 
service innovations (0.07) and scientific $R \& D(0.04)$. As a general result, architectural and engineering designs are the most important component of innovative property capital in all sectors, except in manufacturing.

The growth contributions of economic competencies are less spread across industries than those of innovative properties. Economic competencies have raised labour productivity growth between 0.11 (construction) and 0.22 (utility) percentage points. In manufacturing these competencies have stimulated growth by roughly 0.17 percentage points. Among economic competencies, not all types of assets are equally important. Growth in firm-specific human capital has contributed the most in four out of six sectors (manufacturing, utility, construction and trade\& transport), followed by own-account as well as purchased organizational capital. Regarding the size of these effects, note that the contribution of firm-specific human capital turned out to be higher than that of new architectural and engineering design in all four industries. In the remaining two sectors (financial \& business services and agriculture \& mining) own-account organizational capital was the most important source of growth among economics competencies. Compared to firm-specific human capital and organizational capital, growth in branding capital (advertising) was associated with a relatively smaller increase in labour productivity growth. It was roughly 0.03 percentage points in manufacturing, utility and agriculture \& mining, and more or less negligible in the other three sectors.

The contribution of growth in intangible capital related to investments in computerized information is relatively small in all sectors. It never exceeds 0.1 percentage points. Within computerized information, software is decisive whereas the role of database is negligible.

In order to account for the effect that business cycle conditions were quite different across the period 1997 to 2000, we perform the growth accounting for various sub-periods. Table 4 splits the sample into three periods: the first period 1997-2000 was characterised by an economy-wide boom period. On the contrary, the period 2000-2003 was marked by a recession, whereas the economy experienced an economic upswing again in the period 2003-2006. This is also reflected by the figures on labour productivity growth, except for utility and agriculture \& mining in which we observe highest growth rates in the second period. The results confirm much of what has been said so far, but they also reveal some interesting new insights: The main results can be summarized as follows:

- The contribution of intangible capital to growth turned out to be positive in all sub-periods in all sectors, except for financial \& business services in the third period.

- In most sectors, including manufacturing and the two service sectors, the absolute increase in labour productivity growth due to intangible capital has been declined over the three periods. This decrease can be observed for each single component of intangible capital. It is particularly strong for economic competencies and less so for innovative property and computerized information.

- But still, intangible capital deepening was higher than ICT capital deepening or non-ICT capital deepening in all three periods in manufacturing, agriculture \& mining and construction. In both service sectors, however, this pattern has changed over time and ICT capital deepening (financial business services) and non-ICT capital deepening (trade \& transport) have become more important than intangible capital deepening from 2001 onwards.

- Though the growth in labour productivity was similar in magnitude in manufacturing in the boom period 1997-2000 and in the upswing period 2003-2006, the sources of growth differ quite a lot. 
Besides intermediate input deepening, intangible capital was the second most important source of growth in the first period that has stimulated growth by 1 percentage point whereas the contribution of TFP was relatively small $(+0.5)$. In the third period, however, the upswing is much more supported by growth in TFP $(+1.7)$ than by intangible capital $(+0.25)$. But also the contribution of tangible capital has declined (from +0.36 to +0.16 ).

- In all sectors, the contribution of labour quality to growth in labour productivity was highest in the recession period. 


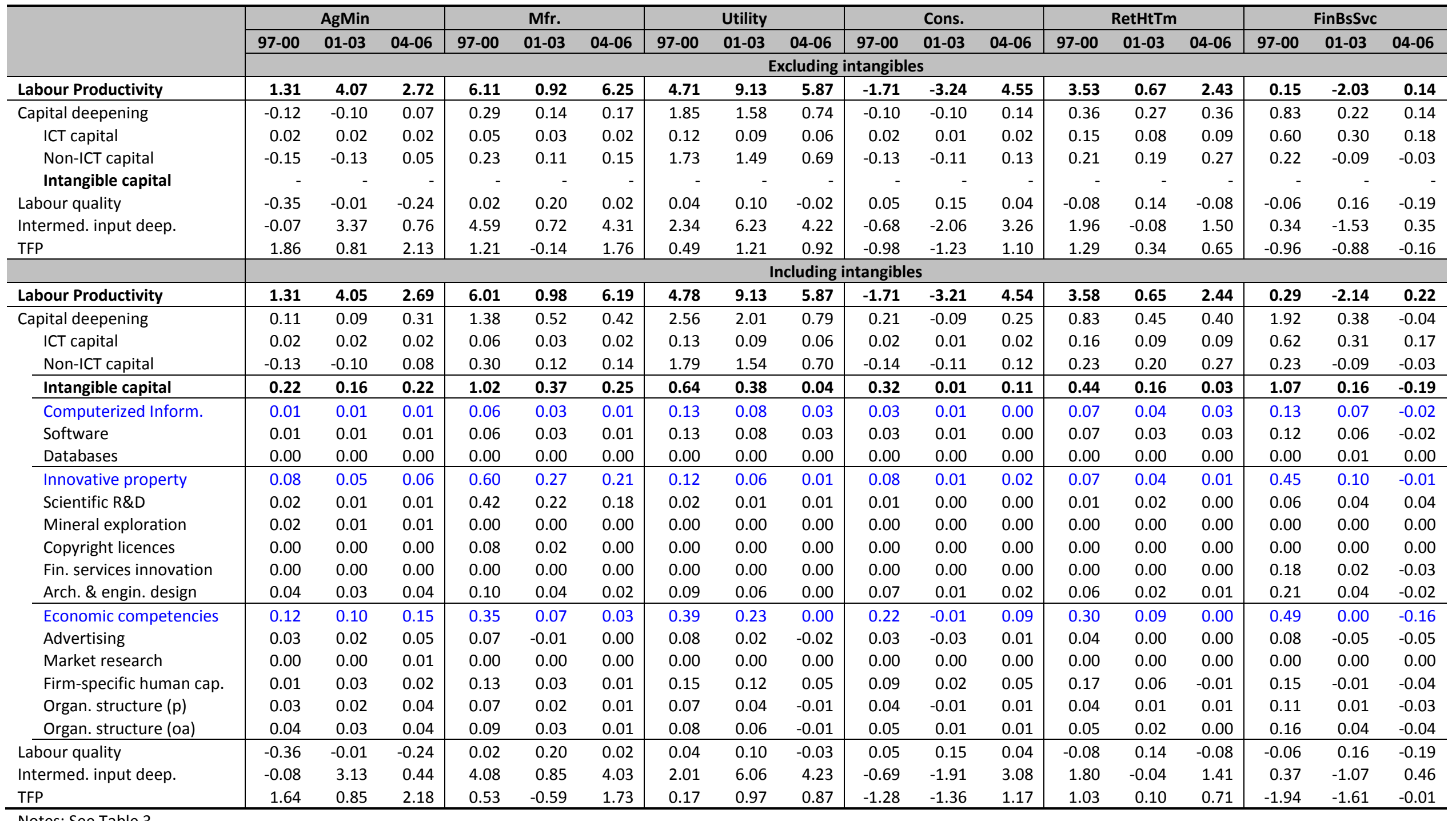




\section{Decomposition of real value added growth at the industry level}

Since growth accounting at the aggregate level is based on a value added concept, Table 5 additionally depicts the decomposition of growth in real value added at the industry level. Growth in real value added in industry $j$ is the weighted sum of industry capital, labour input and TFP growth. The weights on capital (labour) account for the share of capital (labour) income in gross output in industry $\mathrm{j}$ and for (the inverse of) the share of industry value added in industry gross output.

Table 5: $\quad$ Contributions to labour productivity growth (in terms of value added) by sector and type of intangible assets, 1997-2006

\begin{tabular}{|c|c|c|c|c|c|c|}
\hline & AgMin & Mfr. & Utility & Cons. & RetHtTm & FinBsSvc \\
\hline & \multicolumn{6}{|c|}{ Excluding intangibles } \\
\hline Labour productivity growth & 2.90 & 3.73 & 4.60 & -0.85 & 2.13 & -0.54 \\
\hline Capital deepening & -0.12 & 0.61 & 2.81 & -0.06 & 0.63 & 0.83 \\
\hline ICT capital & 0.05 & 0.11 & 0.18 & 0.04 & 0.21 & 0.73 \\
\hline Non-ICT capital & -0.17 & 0.50 & 2.63 & -0.10 & 0.42 & 0.10 \\
\hline Intangible capital & - & - & - & - & - & - \\
\hline Labour quality & -0.47 & 0.22 & 0.07 & 0.18 & -0.02 & -0.06 \\
\hline \multirow[t]{2}{*}{ TFP } & 3.48 & 2.90 & 1.71 & -0.96 & 1.53 & -1.31 \\
\hline & \multicolumn{6}{|c|}{ Including intangibles } \\
\hline Labour productivity growth & 3.09 & 3.65 & 4.65 & -0.77 & 2.16 & -0.69 \\
\hline Capital deepening & 0.34 & 2.03 & 3.37 & 0.29 & 1.02 & 1.40 \\
\hline ICT capital & 0.05 & 0.10 & 0.17 & 0.04 & 0.21 & 0.64 \\
\hline Non-ICT capital & -0.12 & 0.49 & 2.53 & -0.11 & 0.41 & 0.09 \\
\hline Intangible capital & 0.41 & 1.44 & 0.67 & 0.36 & 0.40 & 0.67 \\
\hline Computerized information & 0.03 & 0.10 & 0.15 & 0.03 & 0.08 & 0.11 \\
\hline Software & 0.03 & 0.09 & 0.15 & 0.03 & 0.08 & 0.10 \\
\hline Databases & 0.00 & 0.00 & 0.00 & 0.00 & 0.00 & 0.00 \\
\hline Innovative property & 0.13 & 0.95 & 0.12 & 0.09 & 0.07 & 0.33 \\
\hline Scientific R\&D & 0.03 & 0.71 & 0.02 & 0.01 & 0.01 & 0.07 \\
\hline Mineral exploration & 0.03 & 0.00 & 0.00 & 0.00 & 0.00 & 0.00 \\
\hline Copyright licences & 0.00 & 0.10 & 0.00 & 0.00 & 0.00 & 0.00 \\
\hline Financial services innovation & 0.00 & 0.00 & 0.00 & 0.00 & 0.00 & 0.11 \\
\hline Architectural \& engineering design & 0.08 & 0.14 & 0.10 & 0.08 & 0.06 & 0.15 \\
\hline Economic competencies & 0.25 & 0.40 & 0.40 & 0.24 & 0.25 & 0.24 \\
\hline Advertising & 0.06 & 0.06 & 0.05 & 0.02 & 0.03 & 0.00 \\
\hline Market research & 0.00 & 0.00 & 0.00 & 0.00 & 0.00 & 0.00 \\
\hline Firm-specific human capital & 0.04 & 0.15 & 0.20 & 0.13 & 0.14 & 0.07 \\
\hline Organizational structure $(p)$ & 0.07 & 0.08 & 0.06 & 0.04 & 0.04 & 0.06 \\
\hline Organizational structure (oa) & 0.08 & 0.11 & 0.08 & 0.06 & 0.05 & 0.11 \\
\hline Labour quality & -0.44 & 0.18 & 0.07 & 0.17 & -0.02 & -0.05 \\
\hline TFP & 3.19 & 1.44 & 1.21 & -1.23 & 1.16 & -2.04 \\
\hline
\end{tabular}

Notes: See Table 3.

Most of the results with respect to the sources of growth in value added are qualitatively the same as before for growth in gross output. In a nutshell, the most salient results are the following:

First, the contribution of intangible capital to growth turned out to be positive in all sectors. It is highest in manufacturing where it raised growth by 1.44 percentage points. That is, intangible capital accounts for nearly $40 \%$ of labour productivity growth (based on value added). In the other five industries, intangible capital deepening ranges roughly between 0.35 and 0.7 percentage points and its relative importance is lower.

Second, the former result that intangible capital deepening is more important than ICT and non-ICT capital deepening, respectively, is confirmed for most industries (manufacturing, agriculture \& mining, 
construction, financial \& business services). In the first three of the sectors, the contribution of intangible capital was even larger than that of overall tangible capital. In trade \& transport, non-ICT capital deepening turned out to be slightly more important. In financial \& business services, the contribution of ICT capital was nearly as large as that of intangible capital.

Third, in manufacturing and financial \& business services the growth of innovative property capital is the most influential type of intangible capital for labour productivity. In manufacturing the main source of intangible capital deepening can be again traced back to scientific R\&D (it accounts for $75 \%$ ) whereas it is new architectural and engineering design in financial and business services. In both sectors, innovative property is followed by economic competencies and computerized information is bottom of the list. In all other sectors, the main source of intangible capital deepening can be allotted to the growth in economic competencies. It is followed by innovative property capital and computerized information.

Fourth, with respect to the relative importance of specific types of economic competencies, the same picture emerges as before: Growth in firm-specific human capital has contributed the most in four out of six sectors (manufacturing, utility, construction and trade\& transport), followed by own-account as well as purchased organizational capital. In the remaining two sectors growth in own-account organizational capital was the most important source of growth among economics competencies.

Furthermore, the inclusion of intangible capital reduces the contribution of TFP growth significantly in 5 out of 6 sectors (the exception being agriculture \& mining). The reduction in the contribution of TFP turns out to be particularly strong in those industries where growth in intangible capital revives labour productivity growth to a larger extent. But still, TFP growth plays the most important role for growth in labour productivity based on value added in manufacturing, agriculture $\&$ mining and trade $\&$ transport. Ln manufacturing, e.g., TFP growth raised labour productivity growth by 1.4 percentage points. This corresponds to roughly $40 \%$ of the overall increase in labour productivity. On the contrary, the effect of TFP growth was negative on labour productivity in financial and business services and construction.

Finally, growth in labour quality contributed only to a small extent to industry growth in labour productivity based on value added. The contributions are slightly larger compared to when we use gross output to measure labour productivity, in particular for manufacturing and construction.

\section{Decomposition of real value added growth at the aggregate level}

Using the direct aggregation approach, we calculate aggregate value added growth as weighted sum of industry value added growth and investigate the sources of aggregate growth using equation (8). Table 6 displays the contributions of capital, labour quality and TFP to aggregate growth with (upper panel) and without (bottom panel) accounting for intangible capital.

Note that treating expenditure for intangible goods as intermediate input instead of long-term investment generally implies that we underestimate labour productivity and overestimate the contribution of total factor productivity to labour productivity growth. In the period 1997-2000 we clearly observe these two biases. In the period 2001-2006, however, we would overestimate labour productivity growth when we neglect intangible capital. But in all periods the inclusion of intangible capital leads to a significant reduction in the contribution of TFP to labour productivity growth. Overall, it declined from 1.1 to 0.26 percentage points. 
In the period 1997-2006 the average annual labour productivity growth was nearly $1.8 \%$. The most important contribution to growth stems from intangible capital deepening. It accounts for 0.84 percentage points or nearly half of the overall growth in labour productivity. However, what was already evident at the industry level transferred to the aggregate level: The absolute and relative contribution of intangible capital deepening has declined over time. While labour productivity growth was mainly backed by intangible capital deepening in the boom period 1997-2000, intangible capital contributed only to a small extent to the economic upswing in 2003-2006. Growth in TFP was the main source of labour productivity growth in this period.

Table 6: $\quad$ Contributions to aggregate labour productivity growth, 1997-2006

\begin{tabular}{|c|c|c|c|c|}
\hline & $97-00$ & 01-03 & 04-06 & Tota \\
\hline & \multicolumn{4}{|c|}{ Excluding intangibles } \\
\hline Value added growth & 2.55 & 0.35 & 2.51 & 1.88 \\
\hline Hours worked & 0.41 & -0.01 & -0.30 & 0.07 \\
\hline Labour productivity growth & 2.14 & 0.36 & 2.81 & 1.81 \\
\hline Capital deepening & 0.93 & 0.47 & 0.52 & 0.67 \\
\hline ICT capital & 0.43 & 0.24 & 0.17 & 0.30 \\
\hline Non-ICT capital & 0.50 & 0.23 & 0.35 & 0.37 \\
\hline Intangible capital & - & - & - & - \\
\hline Labour quality & -0.06 & 0.39 & -0.13 & 0.05 \\
\hline \multirow[t]{2}{*}{ TFP } & 1.28 & -0.50 & 2.42 & 1.09 \\
\hline & \multicolumn{4}{|c|}{ Including intangibles } \\
\hline Value added growth & 2.81 & 0.01 & 2.47 & 1.87 \\
\hline Hours worked & 0.41 & 0.04 & -0.29 & 0.09 \\
\hline Labour productivity growth & 2.40 & -0.03 & 2.75 & 1.78 \\
\hline Capital deepening & 2.49 & 0.93 & 0.64 & 1.47 \\
\hline ICT capital & 0.39 & 0.21 & 0.15 & 0.27 \\
\hline Non-ICT capital & 0.51 & 0.22 & 0.31 & 0.36 \\
\hline Intangible capital & 1.58 & 0.50 & 0.19 & 0.84 \\
\hline Labour quality & -0.05 & 0.35 & -0.12 & 0.05 \\
\hline TFP & -0.04 & -1.31 & 2.23 & 0.26 \\
\hline
\end{tabular}

Notes: See Table 3.

Compared to tangible capital, it turns out that the contribution of intangible capital was larger in the overall period ( +0.84 compared to +0.64 percentage points). However, this was mainly due to the boom period 1997-2000. Between 2001 and 2003 tangible and intangible capital contributed to a similar extent to labour productivity growth ( +0.43 and +0.5$)$. In the upswing phase $2003-2006$, tangible capital deepening, however, was more important as source of growth than intangible capital $(+0.46$ compared to +0.19 ). In the latter period, we even observe that non-ICT capital stimulated growth more than intangible capital and that ICT capital deepening was nearly as large. Overall, the results reveal a decline over time in the absolute contribution of ICT capital and intangible capital whereas we do not observe this pattern for non-ICT capital.

\section{Industry contributions to aggregate labour productivity growth and to capital, labour and TFP deepening}

Finally, the direct aggregation approach allows us to investigate the industry contributions to value added growth (using equation (6)) and to capital, labour and TFP deepening (using equation (7)). Table 7 and Table 8 present the industry contributions when we exclude and include intangible capital into the growth accounting framework. For each sector and indicator (value added, capital, labour and TFP) the weight, growth rate and the sector contribution to the aggregate figure is displayed. 
Industry contributions to aggregate growth (excluding intangibles), 1997-2006

\begin{tabular}{|c|c|c|c|c|c|c|c|c|c|c|c|c|c|c|}
\hline & \multicolumn{14}{|c|}{ Excluding intangibles } \\
\hline & \multicolumn{2}{|c|}{ AgMin } & \multicolumn{2}{|c|}{ Mfr. } & \multicolumn{2}{|c|}{ Utility } & \multicolumn{2}{|c|}{ Cons. } & \multicolumn{2}{|c|}{ RetHtTm } & \multicolumn{2}{|c|}{ FinBsSvc } & \multicolumn{2}{|c|}{ Business Sector } \\
\hline & abs. & in $\%$ & abs. & in $\%$ & abs. & in $\%$ & abs. & in $\%$ & abs. & in $\%$ & abs. & in $\%$ & abs. & in $\%$ \\
\hline \multicolumn{15}{|l|}{ Value added } \\
\hline VA weight & 0.024 & & 0.336 & & 0.032 & & 0.074 & & 0.270 & & 0.264 & & & \\
\hline VA growth & 2.898 & & 3.730 & & 4.598 & & -0.847 & & 2.133 & & -0.542 & & & \\
\hline CT to agg. VA growth & 0.071 & 3.9 & 1.255 & 69.4 & 0.138 & 7.6 & -0.086 & -4.8 & 0.576 & 31.9 & -0.146 & -8.1 & 1.808 & 100.0 \\
\hline \multicolumn{15}{|l|}{ Total capital } \\
\hline Capital weight & 0.002 & & 0.077 & & 0.019 & & 0.011 & & 0.055 & & 0.106 & & & \\
\hline Capital growth & -1.418 & & 2.737 & & 4.853 & & -0.354 & & 3.112 & & 1.974 & & & \\
\hline $\begin{array}{l}\text { CT to agg. capital growth } \\
\text { thereof: }\end{array}$ & -0.003 & -0.5 & 0.204 & 30.6 & 0.089 & 13.4 & -0.007 & -1.1 & 0.170 & 25.5 & 0.213 & 32.0 & 0.666 & 100.0 \\
\hline CT to agg. ICT cap. growth & 0.001 & 0.3 & 0.037 & 12.5 & 0.006 & 2.0 & 0.003 & 1.0 & 0.058 & 19.7 & 0.190 & 64.4 & 0.295 & 100.0 \\
\hline $\mathrm{CT}$ to agg. non-ICT cap. growth & -0.005 & -1.3 & 0.167 & 45.0 & 0.083 & 22.4 & -0.010 & -2.7 & 0.112 & 30.2 & 0.024 & 6.5 & 0.371 & 100.0 \\
\hline CT to intangible cap. growth & - & & & & - & & - & & - & & - & & - & \\
\hline \multicolumn{15}{|l|}{ Labour quality growth (LQG) } \\
\hline Labour quality weight & 0.022 & & 0.259 & & 0.013 & & 0.063 & & 0.216 & & 0.158 & & & \\
\hline Labour quality growth & -0.507 & & 0.275 & & 0.159 & & 0.211 & & -0.029 & & -0.097 & & & \\
\hline $\mathrm{CT}$ to agg. LQG & -0.011 & -20.0 & 0.073 & 132.7 & 0.002 & 3.6 & 0.014 & 25.5 & -0.006 & -10.9 & -0.017 & -30.9 & 0.055 & 100.0 \\
\hline \multicolumn{15}{|l|}{ TFP } \\
\hline TFP weight & 0.051 & & 1.003 & & 0.063 & & 0.170 & & 0.507 & & 0.501 & & & \\
\hline TFP growth & 1.565 & & 0.970 & & 0.833 & & -0.430 & & 0.814 & & -0.699 & & & \\
\hline $\mathrm{CT}$ to agg. TFP growth & 0.072 & 6.6 & 0.977 & 89.9 & 0.047 & 4.3 & -0.092 & -8.5 & 0.412 & 37.9 & -0.342 & -31.5 & 1.087 & 100.0 \\
\hline
\end{tabular}

Notes: Presented are average annual industry contributions. Data: See section 2 and 6.2. Own calculation. 


\begin{tabular}{|c|c|c|c|c|c|c|c|c|c|c|c|c|c|c|}
\hline & \multicolumn{14}{|c|}{ Including intangibles } \\
\hline & \multicolumn{2}{|c|}{ AgMin } & \multicolumn{2}{|c|}{ Mfr. } & \multicolumn{2}{|c|}{ Utility } & \multicolumn{2}{|c|}{ Cons. } & \multicolumn{2}{|c|}{ RetHtTm } & \multicolumn{2}{|c|}{ FinBsSvc } & \multicolumn{2}{|c|}{ Business Sector } \\
\hline & abs. & in \% & abs. & in $\%$ & abs. & in $\%$ & abs. & in \% & abs. & in $\%$ & abs. & in \% & abs. & in $\%$ \\
\hline \multicolumn{15}{|l|}{ Value added } \\
\hline VA weight & 0.022 & & 0.354 & & 0.030 & & 0.068 & & 0.255 & & 0.270 & & & \\
\hline VA growth & 3.086 & & 3.650 & & 4.646 & & -0.766 & & 2.158 & & -0.691 & & & \\
\hline CT to agg. VA growth & 0.069 & 3.9 & 1.291 & 72.7 & 0.132 & 7.4 & -0.074 & -4.2 & 0.549 & 30.9 & -0.190 & -10.7 & 1.777 & 100.0 \\
\hline \multicolumn{15}{|l|}{ Total capital } \\
\hline Capital weight & 0.003 & & 0.125 & & 0.018 & & 0.013 & & 0.064 & & 0.131 & & & \\
\hline Capital growth & 2.538 & & 5.882 & & 5.549 & & 1.574 & & 4.090 & & 2.744 & & & \\
\hline $\begin{array}{l}\text { CT to agg. capital growth } \\
\text { thereof: }\end{array}$ & 0.007 & 0.5 & 0.716 & 48.7 & 0.101 & 6.9 & 0.020 & 1.4 & 0.260 & 17.7 & 0.365 & 24.8 & 1.469 & 100.0 \\
\hline CT to agg. ICT cap. growth & 0.001 & 0.4 & 0.035 & 13.2 & 0.005 & 1.9 & 0.003 & 1.1 & 0.052 & 19.6 & 0.169 & 63.8 & 0.265 & 100.0 \\
\hline CT to agg. non-ICT cap. growth & -0.003 & -0.8 & 0.173 & 47.5 & 0.076 & 20.9 & -0.010 & -2.7 & 0.105 & 28.8 & 0.023 & 6.3 & 0.364 & 100.0 \\
\hline CT to intangible cap. growth & 0.009 & 1.1 & 0.508 & 60.5 & 0.020 & 2.4 & 0.027 & 3.2 & 0.103 & 12.3 & 0.172 & 20.5 & 0.839 & 100.0 \\
\hline \multicolumn{15}{|l|}{ Labour quality growth (LQG) } \\
\hline Labour quality weight & 0.019 & & 0.229 & & 0.012 & & 0.056 & & 0.190 & & 0.140 & & & \\
\hline Labour quality growth & -0.507 & & 0.275 & & 0.159 & & 0.211 & & -0.029 & & -0.097 & & & \\
\hline CT to agg. LQG & -0.010 & -20.8 & 0.064 & 133.3 & 0.002 & 4.2 & 0.012 & 25.0 & -0.005 & -10.4 & -0.015 & -31.3 & 0.048 & 100.0 \\
\hline \multicolumn{15}{|l|}{ TFP } \\
\hline TFP weight & 0.045 & & 0.886 & & 0.055 & & 0.150 & & 0.447 & & 0.442 & & & \\
\hline TFP growth & 1.565 & & 0.556 & & 0.620 & & -0.570 & & 0.657 & & -1.262 & & & \\
\hline $\mathrm{CT}$ to agg. TFP growth & 0.072 & 27.5 & 0.511 & 195.0 & 0.030 & 11.5 & -0.106 & -40.5 & 0.294 & 112.2 & -0.539 & -205.7 & 0.262 & 100.0 \\
\hline
\end{tabular}

Notes: Presented are average annual industry contributions. Data: See section 2 and 6.2. Own calculation. 
With respect to value added, the lion's share can be allotted to manufacturing. $73 \%$ of aggregate value added growth stems from manufacturing despite its share in aggregate value added being just around $35 \%$. A second important source of aggregate value added growth originates in trade \& transport (roughly 31\%). On the contrary, construction and financial \& business services have contributed negatively to value added growth.

Regarding the contribution of labour quality, we also find manufacturing on the top of the list though its relative size in labour is smaller than for instance for trade $\&$ transport. With respect to ICT capital deepening the leading sector contribution stems from financial \& business services. Around $64 \%$ of the contribution of ICT capital to labour productivity growth comes from this sector. The second largest contributor to ICT capital deepening is trade \& transport (19\%), followed by manufacturing (13\%). Regarding non-ICT capital deepening, the industry contributions are much more evenly spread across industries. The major contributor is manufacturing. Its contribution (48\%) is again larger than the weight manufacturing possesses in the level of aggregate value added. Trade $\&$ transport is second on the list (29\%), followed by utility (21\%).

Intangible capital deepening stems to a large extent from high growth rates in intangibles in manufacturing. $60.5 \%$ of the contribution of intangible capital to labour productivity can be traced back to manufacturing. The financial and business services sector is the second largest contributor to intangible capital deepening (21.5\%). Another $12 \%$ originates in trade \& transport.

Aggregate TFP growth is mostly accounted for by manufacturing and trade \& transport. Utility and agriculture show also a positive but relatively small contribution whereas the financial $\&$ business service sector and construction even negatively contribute to aggregate TFP growth.

\section{Conclusion}

Knowledge investment has become a key factor for firms around the world to gain competitive advantage and firms across different sectors are likely to differ in their strategies to invest in intangible capital. This study was aimed at shedding light on the role of intangible assets for growth at the sector level in Germany. The assessment was done by comparing efforts across countries (to be precise with the UK) and by calculating their contribution to industry growth in labour productivity.

Our results show that German firms have intensified their efforts to invest in intangible capital. In absolute terms, investment has grown from 138.6 bn $€$ to 180 bn $€$ over the period 1995-2006 which corresponds to a growth rate of $30 \%$. This increase was not continuous but followed the overall economic development. We furthermore showed that intangible investment gained importance relative to tangible investment. Its share increased from $80 \%$ to $89 \%$. Despite this positive trend, we have to ascertain that the increase in gross output was even larger. That is, the share of intangible investment in gross output has fallen in the two largest sectors, manufacturing (from $6.7 \%$ to $5.6 \%$ ) and financial and business services (from 9.1\% to 8.1).

In Germany, nearly half of the investment in intangibles is carried out by manufacturing firms. This industry proportion is much higher than the share of manufacturing in gross output, value added or 
for instance in labour input. The outstanding position of intangible capital in manufacturing is also documented by the fact that this sector invests more in intangible than tangible capital and that this proportion has even climbed from $138 \%$ to $168 \%$. Financial and business services account for about one third of all intangible investments. Though firms in this sector have expanded their investment for intangible capital the importance relative to tangible capital is nearly unaltered (around $80 \%$ ).

In particular, German firms have expanded their investment in computerized information by nearly $100 \%$. At the same time, a shift has taken place in investment in software and databases from manufacturing towards business services. Despite this intensification, the share of computerized information in overall investment in intangibles remains rather small. Software and databases account for $10 \%$ in the business sector in 2004 . This share, however, varies across industries between $5 \%$ in agriculture \& mining and $21 \%$ in utility, manufacturing is at the lower end $(6 \%)$ and financial and business in the mid (11\%).

Investment in innovative property makes up 55\% of all intangible investment in 2004 . It has also demonstrated a positive trend though it has been less marked than in computerized information. From 1995 to 2008 investment in innovative property has grown by $40 \%$. The investments are highly concentrated in two industries, namely manufacturing and financial and business services. Manufacturing firms do not only perform most of the investment in innovative property in general and R\&D in specific, but innovative property is likewise the most important type of intangible asset in this sector (55\%). Compared to other intangible assets, innovative property is far less important in financial and business services (27\%) and trade and transport (28\%).

Investments in economic competencies have increased by $25 \%$. They are less concentrated across sectors and the distribution across industries is quite stable over the period. The relative importance of economic competencies varies quite a lot across sectors. Manufacturing firms direct $39 \%$ of their investments in intangibles to economic competencies. This share is above $60 \%$ in all other industries, being highest in construction with $78 \%$.

Compared to the UK, the share of intangible investment in gross output is smaller in all sectors in Germany except for utility. A more differentiated picture, however, can be drawn when we look at distinct asset classes. For instance, manufacturing firms in Germany invest a higher proportion of gross output in R\&D and in advertising whereas investment in new designs, software, organizational structure, firm-specific human capital and copyright and licences are higher in the UK. In general, investment in new architectural and engineering design is consistently higher across all sectors in the UK. Computerized information is around two times larger in UK manufacturing, financial and business services and trade $\&$ transport (similar shares in other three sectors). On the other hand, German firms invest a higher proportion of gross output in R\&D in all sectors. Advertising is also more common in Germany except for the sector trade \& transport.

The decomposition of the sources of growth between primary inputs and TFP emphasizes that intermediate inputs contributed the most to labour productivity growth in all sectors in Germany, except in financial and business services. Growth in labour quality contributed only to a very limited extent to industry growth in labour productivity. The contribution of tangible capital to growth is also relatively small, except for utility. Whereas non-ICT capital is much more important for generating growth in sectors such as manufacturing, trade \& transport and utility, ICT has a larger contribution 
in the other three sectors. Extending the growth accounting framework, we corroborate that growth in intangible assets has stimulated labour productivity growth in all sectors. The contribution varies between 0.17 (construction) and 0.59 (manufacturing) percentage points. Compared to the UK, however, intangible capital deepening seems to be somewhat smaller in absolute and relative terms in most sectors in Germany. The contribution of intangible capital turns out to be higher than that of ICT and non ICT capital separately in all German sectors, except for utility. Growth in TFP plays a major role in explaining industry growth in labour productivity but its contribution decreases when we include intangible capital in all sectors.

The results further highlight hat growth of innovative property capital is the most influential type of intangible capital for labour productivity in manufacturing and financial \& business services, followed by economic competencies and computerized information. In all other sectors, growth of intangible capital that measures economic competencies plays the most prominent role for labour productivity growth, followed by innovative property capital and computerized information. The absolute contribution of growth in intangible capital related to investment in computerized information is relatively small in all sectors.

But it is also worthy to compare the relative contribution. In manufacturing, for instance, innovative property accounts for $55 \%$ of intangible investment, but for $65 \%$ of the total contribution of intangible capital. In the financial and business service sector this deviation is even more pronounced. $27 \%$ of intangible investments are allotted to innovative property which accounts for nearly $50 \%$ of the growth contribution of intangible capital. The growth contribution is likewise comparably high for computerized information. In financial and business services this item makes up $11 \%$ of intangible investment, but $16 \%$ of its growth contribution. In manufacturing, the corresponding shares are $5 \%$ and $6.7 \%$. In contrast, economic competencies are relatively less growth-enhancing. In manufacturing, they account for $39 \%$ of intangible investment, but only for $28 \%$ of the total contribution of intangible capital. In financial and business services this difference is even larger. $62 \%$ of intangible investment is allotted to economic competencies. But they make up only $35 \%$ of the growth contribution of intangible capital. 
Azeez Erumban, A. (2008), Capital Aggregation and Growth Accounting: A Sensitivity Analysis, EU KLEMS Working Paper 25, Groningen.

Chun, H., Fukao, K., Shoichi, H. and Tsutomu, M. (2012), Measurement of Intangible Investments by Industry and its Role in Productivity Improvement Utilizing Comparative Studies Between Japan and Korea, RIETI Discussion Paper Series 12-E-037, Research Institute of Economy, Trade and Industry (RIETI).

Clayton, T., Dal Borgo, M. and Haskel, J. (2009), An Innovation Index Based on Knowledge Capital Investment: Definition and Results for the UK Market Sector, IZA Discussion Paper No. 4021, Bonn.

Corrado, C., Haltiwanger, J. and Sichel, D. (2005), Measuring Capital and Technology: An Expanded Framework, in Corrado, C., Haltiwanger, J. and Sichel, D. (eds), Measuring Capital in the New Economy, Chicago: University of Chicago Press, 11-46.

Corrado, C., Hulten, C. and Sichel, D. (2009), Intangible capital and economic growth, The Review of Income and Wealth 55(3), 661-685.

Crass, D., Licht, G., Peters, B. and Sofka, W. (2010), Time Series Estimates of Intangible Investments Sensitivity Analysis for Germany, Mannheim.

Delbecque, V. and Nayman, L. (2010), Measuring intangible capital investment: An application to the French data, Working Papers 2010-19, CEPII Research Center, Paris.

Edquist, H. (2011), Can Investment in Intangibles Explain the Swedish Productivity Boom in the 1990s?, Review of Income and Wealth 57(4), 658-682.

Fukao, K., Miyagawa, T., Mukai, K., Shinoda, Y. and Tonogi, K. (2009), Intangible Investment in Japan: Measurement and Contribution to Economic Growth, Review of Income and Wealth 55(3), 717736.

Gil, V. and Haskel, J. (2008), Industry-level Expenditure on Intangible Assets in the UK, http://www.coinvest.org.uk/bin/view/Colnvest/CoinvestGilHaspaper.

Goodridge, P., Haskel, J. \& Wallis, G. (2012). UK Innovation Index: Productivity and Growth in UK Industries, CEPR Discussion Papers 9063, London.

Hall, R. and Jorgenson, D. W. (1967), Tax policy and investment behaviour, American Economic Review, 57(3), 391-414.

Hao, J. and Manole, V. (2008), Intangible Capital and Growth - an International Comparison, paper prepared for the 30th General Conference of the International Association for Research in Income and Wealth, http://www.iariw.org.

Hao, J., Manole, V. and van Ark, B. (2009), Intangible Capital and Growth - an International Comparison, Coinvest Deliverable D3.6: Paper quantifying figures on time-series estimates dating back to 1980 for Germany, Brussels.

Jorgenson, D. W. (1963), Capital theory and investment behaviour, American Economic Review 53(2), 247-259. 
Jorgenson, D. W., Gollop, F. M. and Fraumeni, B. M. (1987), Productivity and U.S. Economic Growth, Cambridge: Harvard University Press.

Jorgenson, D. W. and Griliches, Z. (1967), The Explanation of Productivity Change, The Review of Economic Studies 34 (3), 249-283.

Jorgenson, D. W., Ho, M. S. and Stiroh, K. J. (2005), Growth of U.S. Industries and Investments in Information Technology and Higher Education, in: Corrado, C., Haltiwanger, J. and Sichel, D. (2005), Measuring Capital in the New Economy, Chicago: University of Chicago Press, 403-478.

Jorgenson, D. W., Ho, M. S., Samuels, J. D. and Stiroh, K. J. (2007), Industry Origins of the American Productivity Resurgence, Economic Systems Research 19, 229-252.

Landes, E. M. and Rosenfield, A. M. (1994). The Durability of Advertising Revisited, Journal of Industrial Economics 42, 263-276.

Marrano, G. and Haskel, J. (2006), How Much Does the UK Invest in Intangible Assets?, Queen Mary University of London Working Paper 578, London.

Nakamura, L. (2001), What is the US Gross Investment in Intangibles? (At Least) One Trillion Dollars a Year!, Federal Reserve Bank of Philadelphia Working Paper No. 01-15.

Niebel, T., O'Mahony, M. and Saam, M. (2013), The Contribution of Intangible Assets to Sectoral Productivity Growth in the EU, ZEW Discussion Paper 13-062, Mannheim.

OECD (2001), Measuring Capital: OECD Manual, Annex 1 Glossary of Technical Terms Used in the Manual, Paris.

OECD (2002), Frascati Manual: Proposed Standard Practice for Surveys on Research and Experimental Development, OECD, Paris.

OECD and Eurostat (2005), Oslo Manual - Guidelines for Collecting and Interpreting Innovation Data, Paris, 3rd ed.

O'Mahony, M. and Peng, F. (2011), Intangible Training Capital and Productivity in Europe, MPRA Paper 38648.

Peters, B. and Rammer, C. (2013), Innovation Panel Surveys in Germany, in: Gault, F. (ed), Handbook of Innovation Indicators and Measurement, Edward Elgar, Cheltenham and Northampton, 135177.

Statistisches Bundesamt (2006), Wirtschaft und Statistik 9/2006, Wiesbaden

Statistisches Bundesamt (2010), Wirtschaft und Statistik 1/2010, Wiesbaden

Werner, D. (2006), Trends und Kosten der betrieblichen Weiterbildung - Ergebnisse der IWWeiterbildungserhebung 2005, in: IW-Trends, 33 (1), 17-33.

ZAW Zentralverband der deutschen Werbewirtschaft (1991-2008), Werbung in Deutschland, Verlag edition ZAW, Berlin. 


\section{Data Appendix}

Table 9: Data sources

\begin{tabular}{|c|c|c|c|c|}
\hline $\begin{array}{l}\text { Investment } \\
\text { item }\end{array}$ & Sources & Calculation & $\begin{array}{l}\text { Industry breakdown } \\
\text { availability }\end{array}$ & $\begin{array}{l}\text { Period } \\
\text { available }\end{array}$ \\
\hline \multicolumn{5}{|c|}{ Computerized information } \\
\hline Software & EU KLEMS Nov2009 Release & Calculated by EU KLEMS & $\begin{array}{l}\text { Industry breakdown } \\
\text { available in EU KLEMS } \\
\text { Nov2009 data }\end{array}$ & 1991-2007 \\
\hline Databases & $\begin{array}{l}\text { German Federal Statistical } \\
\text { Office: Turnover tax statistics }\end{array}$ & Turnover of NACE 72.4 & Input-Output Table (K72) & 1994-2008 \\
\hline \multicolumn{5}{|c|}{ Innovative property } \\
\hline Scientific R\&D & EUROSTAT: ANBERD & Calculated by ANBERD & $\begin{array}{l}\text { Industry breakdown } \\
\text { available in ANBERD data }\end{array}$ & 1991-2006 \\
\hline $\begin{array}{l}\text { Mineral } \\
\text { exploration }\end{array}$ & $\begin{array}{l}\text { German Federal Statistical } \\
\text { Office: Turnover tax statistics }\end{array}$ & Turnover of NACE 45.12 & no breakdown & 1994-2008 \\
\hline $\begin{array}{l}\text { Copyright } \\
\text { licences }\end{array}$ & $\begin{array}{l}\text { German Federal Statistical } \\
\text { Office: Turnover tax statistics }\end{array}$ & Turnover of NACE 92.11 & Input-Output Table (K92) & $1992-2008$ \\
\hline $\begin{array}{l}\text { Financial } \\
\text { services } \\
\text { innovation }\end{array}$ & $\begin{array}{l}\text { Mannheim Innovation Panel } \\
\text { (MIP) }\end{array}$ & $\begin{array}{l}\text { Extrapolation of innovation } \\
\text { expenditures to the total } \\
\text { population of enterprises } \\
\text { in the financial industry. }\end{array}$ & no breakdown & 1995-2007 \\
\hline $\begin{array}{l}\text { Architectural \& } \\
\text { engineering } \\
\text { design }\end{array}$ & $\begin{array}{l}\text { German Federal Statistical } \\
\text { Office: Turnover tax statistics }\end{array}$ & Turnover of NACE 74.2 & Input-Output Table (K74) & $1992-2008$ \\
\hline \multicolumn{5}{|c|}{ Economic competencies } \\
\hline Advertising & $\begin{array}{l}\text { Central Association of the } \\
\text { German Advertising Industry } \\
\text { (ZAW) \& Mannheim } \\
\text { Innovation Panel (MIP) }\end{array}$ & $\begin{array}{l}\text { Gross advertising } \\
\text { expenditure (ZAW) plus } \\
15 \% \text { for own-account } \\
\text { marketing expenditures } \\
\text { (based on MIP) }\end{array}$ & Input-Output Table (K74) & 1991-2008 \\
\hline $\begin{array}{l}\text { Market } \\
\text { research }\end{array}$ & $\begin{array}{l}\text { German Federal Statistical } \\
\text { Office: Turnover tax statistics }\end{array}$ & Turnover of NACE 74.13 & Input-Output Table (K74) & 1994-2008 \\
\hline $\begin{array}{l}\text { Firm-specific } \\
\text { human capital }\end{array}$ & $\begin{array}{l}\text { Mannheim Innovation Panel } \\
\text { (MIP) }\end{array}$ & $\begin{array}{l}\text { Extrapolation of training } \\
\text { expenditures. }\end{array}$ & $\begin{array}{l}\text { Industry breakdown } \\
\text { available in MIP data }\end{array}$ & 1995-2006 \\
\hline $\begin{array}{l}\text { Organizational } \\
\text { structure }(p)\end{array}$ & $\begin{array}{l}\text { German Federal Statistical } \\
\text { Office: Turnover tax statistics }\end{array}$ & Turnover of NACE 74.14.1 & Input-Output Table (K74) & 1994-2008 \\
\hline $\begin{array}{l}\text { Organizational } \\
\text { structure (oa) }\end{array}$ & $\begin{array}{l}\text { German Federal Statistical } \\
\text { Office: Structure of earnings } \\
\text { survey } 2006 \text { (wage bill of } \\
\text { salaries of senior managers in } \\
\text { the private sector) \& EU } \\
\text { KLEMS Nov2009 }\end{array}$ & $\begin{array}{l}20 \% \text { of managers' } \\
\text { compensation }\end{array}$ & Input-Output Table (K74) & 1991-2007 \\
\hline
\end{tabular}

Source: own representation. 
Table 10: Investment in intangible assets in the business sector, 1994-2008 (bn Euro)

\begin{tabular}{|c|c|c|c|c|c|c|c|c|c|c|c|c|c|c|c|}
\hline Type of Investment & 1994 & 1995 & 1996 & 1997 & 1998 & 1999 & 2000 & 2001 & 2002 & 2003 & 2004 & 2005 & 2006 & 2007 & 2008 \\
\hline \multicolumn{16}{|l|}{ Computerized information } \\
\hline Software & 9.0 & 9.5 & 10.3 & 11.1 & 12.1 & 13.6 & 15.0 & 15.9 & 15.7 & 15.5 & 15.8 & 16.0 & 16.8 & 17.7 & n.a. \\
\hline Databases & 0.1 & 0.1 & 0.1 & 0.1 & 0.1 & 0.3 & 0.4 & 0.5 & 0.6 & 0.3 & 0.3 & 0.3 & 0.6 & 0.5 & 0.7 \\
\hline \multicolumn{16}{|l|}{ Innovative property } \\
\hline Scientific R\&D & 25.9 & 26.8 & 27.2 & 28.9 & 30.3 & 33.6 & 35.6 & 36.3 & 36.9 & 38.0 & 38.4 & 38.6 & 41.1 & 43.0 & 46.1 \\
\hline Mineral exploration & 0.0 & 0.1 & 0.1 & 0.1 & 0.1 & 0.1 & 0.1 & 0.1 & 0.1 & 0.1 & 0.1 & 0.1 & 0.1 & 0.1 & 0.2 \\
\hline Copyright licences & 3.4 & 3.9 & 4.4 & 4.5 & 6.8 & 5.8 & 5.4 & 5.1 & 4.0 & 4.3 & 4.0 & 4.1 & 3.8 & 3.5 & 3.7 \\
\hline Financial services innovation & n.a. & 3.9 & 3.6 & 4.2 & 5.8 & 6.6 & 5.5 & 4.9 & 5.1 & 4.7 & 4.0 & 4.9 & 4.4 & 4.4 & 3.2 \\
\hline Architectural \& engineering design & 18.9 & 19.0 & 19.1 & 18.3 & 18.8 & 18.5 & 18.5 & 18.9 & 18.4 & 17.8 & 17.4 & 18.2 & 19.1 & 20.3 & 22.2 \\
\hline \multicolumn{16}{|l|}{ Economic competencies } \\
\hline Advertising & 17.9 & 18.9 & 19.4 & 20.0 & 20.8 & 21.7 & 22.9 & 21.7 & 20.4 & 19.9 & 20.2 & 20.4 & 20.9 & 21.2 & 21.2 \\
\hline Market research & 2.1 & 1.9 & 1.8 & 1.5 & 1.4 & 1.5 & 1.3 & 1.3 & 1.4 & 1.5 & 1.8 & 1.6 & 1.6 & 1.7 & 1.8 \\
\hline Firm-specific human capital & n.a. & 30.3 & 32.5 & 32.2 & 33.9 & 30.6 & 33.0 & 34.5 & 35.7 & 32.1 & 32.5 & 34.2 & 35.6 & n.a. & n.a. \\
\hline Organizational structure (p) & 8.3 & 9.0 & 9.8 & 11.0 & 13.2 & 17.0 & 19.5 & 20.4 & 18.1 & 16.1 & 16.4 & 17.6 & 19.3 & 20.0 & 19.8 \\
\hline Organizational structure (oa) & 14.2 & 14.7 & 14.8 & 14.9 & 15.2 & 15.5 & 16.2 & 16.5 & 16.5 & 16.5 & 16.6 & 16.6 & 16.9 & 17.4 & n.a. \\
\hline Total investment in intangibles & n.a. & 138.2 & 143.1 & 146.9 & 158.6 & 164.8 & 173.4 & 176.2 & 172.9 & 166.9 & 167.4 & 172.6 & 180.1 & n.a. & n.a. \\
\hline
\end{tabular}

Notes: n.a.: figure not available. All figures in bn Euro.

Source: German turnover tax statistics, Mannheim Innovation Panel (MIP), German Structure of Earnings Survey 2006, EU KLEMS Nov2009 Release, Input-Output Table, ZAW; own calculation. 
Table 11: Investment in software and databases by industries, 1994-2007

\begin{tabular}{|c|c|c|c|c|c|c|c|c|c|c|c|c|c|}
\hline & Business & AgMin & & Mfr. & & Utility & & Cons. & & RetHtTrn & & BsSvc & \\
\hline & Sector & bn $€$ & $\%$ & bn $€$ & $\%$ & bn $€$ & $\%$ & $b n €$ & $\%$ & bn $€$ & $\%$ & $b n €$ & $\%$ \\
\hline & \multicolumn{13}{|c|}{ Investment in computer software } \\
\hline 1991 & 8.09 & 0.07 & 0.9 & 3.53 & 43.7 & 0.34 & 4.2 & 0.38 & 4.7 & 2.17 & 26.8 & 1.60 & 19.7 \\
\hline 1992 & 8.59 & 0.08 & 0.9 & 3.45 & 40.1 & 0.37 & 4.3 & 0.44 & 5.1 & 2.47 & 28.8 & 1.78 & 20.8 \\
\hline 1993 & 8.79 & 0.07 & 0.8 & 2.99 & 34.0 & 0.44 & 5.0 & 0.49 & 5.6 & 2.80 & 31.9 & 1.99 & 22.7 \\
\hline 1994 & 8.97 & 0.07 & 0.8 & 3.00 & 33.5 & 0.48 & 5.3 & 0.50 & 5.6 & 2.65 & 29.5 & 2.27 & 25.3 \\
\hline 1995 & 9.48 & 0.09 & 0.9 & 3.41 & 36.0 & 0.39 & 4.1 & 0.44 & 4.6 & 2.51 & 26.4 & 2.64 & 27.9 \\
\hline 1996 & 10.27 & 0.09 & 0.9 & 3.77 & 36.7 & 0.52 & 5.0 & 0.41 & 4.0 & 2.60 & 25.3 & 2.89 & 28.1 \\
\hline 1997 & 11.14 & 0.08 & 0.7 & 4.04 & 36.2 & 0.52 & 4.7 & 0.38 & 3.4 & 2.78 & 25.0 & 3.35 & 30.1 \\
\hline 1998 & 12.14 & 0.08 & 0.7 & 4.41 & 36.3 & 0.53 & 4.3 & 0.39 & 3.2 & 3.00 & 24.7 & 3.73 & 30.7 \\
\hline 1999 & 13.60 & 0.09 & 0.7 & 4.76 & 35.0 & 0.54 & 4.0 & 0.43 & 3.2 & 3.24 & 23.8 & 4.54 & 33.4 \\
\hline 2000 & 15.01 & 0.09 & 0.6 & 5.08 & 33.8 & 0.50 & 3.3 & 0.45 & 3.0 & 3.61 & 24.0 & 5.29 & 35.3 \\
\hline 2001 & 15.90 & 0.08 & 0.5 & 5.27 & 33.2 & 0.50 & 3.2 & 0.36 & 2.3 & 3.44 & 21.6 & 6.25 & 39.3 \\
\hline 2002 & 15.68 & 0.09 & 0.6 & 5.46 & 34.8 & 0.57 & 3.6 & 0.37 & 2.4 & 3.74 & 23.9 & 5.44 & 34.7 \\
\hline 2003 & 15.54 & 0.09 & 0.6 & 5.45 & 35.1 & 0.56 & 3.6 & 0.33 & 2.1 & 3.40 & 21.9 & 5.71 & 36.8 \\
\hline 2004 & 15.84 & 0.09 & 0.6 & 5.21 & 32.9 & 0.59 & 3.7 & 0.31 & 2.0 & 3.94 & 24.9 & 5.70 & 36.0 \\
\hline 2005 & 16.00 & 0.09 & 0.6 & 5.15 & 32.2 & 0.66 & 4.2 & 0.30 & 1.9 & 4.21 & 26.3 & 5.58 & 34.9 \\
\hline 2006 & 16.76 & 0.11 & 0.7 & 5.61 & 33.4 & 0.76 & 4.5 & 0.33 & 2.0 & 4.63 & 27.6 & 5.33 & 31.8 \\
\hline \multirow[t]{2}{*}{2007} & 17.68 & 0.11 & 0.6 & 5.66 & 32.0 & 0.83 & 4.7 & 0.33 & 1.9 & 4.76 & 26.9 & 5.99 & 33.9 \\
\hline & & \multicolumn{12}{|c|}{ Investment in databases } \\
\hline 1994 & 0.11 & 0.00 & 0.3 & 0.03 & 25.0 & 0.00 & 1.3 & 0.00 & 0.8 & 0.02 & 21.9 & 0.05 & 50.8 \\
\hline 1995 & 0.12 & 0.00 & 0.2 & 0.03 & 23.1 & 0.00 & 0.9 & 0.00 & 0.7 & 0.02 & 19.5 & 0.07 & 55.6 \\
\hline 1996 & 0.14 & 0.00 & 0.2 & 0.03 & 23.2 & 0.00 & 0.9 & 0.00 & 0.7 & 0.03 & 19.4 & 0.08 & 55.7 \\
\hline 1997 & 0.15 & 0.00 & 0.2 & 0.03 & 23.3 & 0.00 & 0.9 & 0.00 & 0.7 & 0.03 & 19.4 & 0.08 & 55.7 \\
\hline 1998 & 0.14 & 0.00 & 0.2 & 0.03 & 23.6 & 0.00 & 0.9 & 0.00 & 0.6 & 0.03 & 20.0 & 0.08 & 54.6 \\
\hline 1999 & 0.30 & 0.00 & 0.1 & 0.07 & 22.8 & 0.00 & 1.0 & 0.00 & 0.6 & 0.06 & 20.3 & 0.17 & 55.3 \\
\hline 2000 & 0.35 & 0.00 & 0.1 & 0.08 & 22.5 & 0.00 & 0.9 & 0.00 & 0.5 & 0.07 & 20.9 & 0.19 & 55.1 \\
\hline 2001 & 0.48 & 0.00 & 0.1 & 0.10 & 21.4 & 0.00 & 0.9 & 0.00 & 0.4 & 0.10 & 20.7 & 0.27 & 56.5 \\
\hline 2002 & 0.55 & 0.00 & 0.1 & 0.12 & 22.3 & 0.01 & 0.9 & 0.00 & 0.4 & 0.12 & 21.2 & 0.30 & 55.1 \\
\hline 2003 & 0.25 & 0.00 & 0.1 & 0.05 & 20.3 & 0.00 & 1.0 & 0.00 & 0.4 & 0.05 & 19.8 & 0.15 & 58.5 \\
\hline 2004 & 0.26 & 0.00 & 0.1 & 0.05 & 21.1 & 0.00 & 1.0 & 0.00 & 0.4 & 0.05 & 21.0 & 0.15 & 56.4 \\
\hline 2005 & 0.30 & 0.00 & 0.1 & 0.06 & 20.5 & 0.00 & 0.9 & 0.00 & 0.4 & 0.06 & 21.0 & 0.17 & 57.1 \\
\hline 2006 & 0.58 & 0.00 & 0.1 & 0.12 & 20.3 & 0.01 & 0.9 & 0.00 & 0.4 & 0.12 & 20.7 & 0.33 & 57.6 \\
\hline 2007 & 0.54 & 0.00 & 0.1 & 0.11 & 20.3 & 0.01 & 0.9 & 0.00 & 0.4 & 0.11 & 20.7 & 0.31 & 57.6 \\
\hline 2008 & 0.73 & 0.00 & 0.1 & 0.15 & 20.3 & 0.01 & 0.9 & 0.00 & 0.4 & 0.15 & 20.7 & 0.42 & 57.6 \\
\hline
\end{tabular}

Source: See Table 9. Own calculation. 
Table 12: Investment in scientific R\&D by industries, 1991-2008

\begin{tabular}{|c|c|c|c|c|c|c|c|c|c|c|c|c|c|}
\hline & \multirow{2}{*}{$\begin{array}{l}\text { Business } \\
\text { Sector }\end{array}$} & \multicolumn{3}{|c|}{ AgMin } & \multirow{2}{*}{$\begin{array}{r}\text { Mfr. } \\
\%\end{array}$} & \multicolumn{2}{|c|}{ Utility } & \multicolumn{2}{|c|}{ Cons. } & \multicolumn{2}{|c|}{ RetHtTrn } & \multicolumn{2}{|c|}{ FinBsSvc } \\
\hline & & $b n €$ & $\%$ & $b n €$ & & $b n €$ & $\%$ & $b n €$ & $\%$ & $b n €$ & $\%$ & $b n €$ & $\%$ \\
\hline 1991 & 26.25 & 0.22 & 0.9 & 25.20 & 96.0 & 0.14 & 0.5 & 0.09 & 0.3 & 0.14 & 0.5 & 0.46 & 1.7 \\
\hline 1992 & 26.58 & 0.25 & 1.0 & 25.39 & 95.5 & 0.12 & 0.4 & 0.08 & 0.3 & 0.19 & 0.7 & 0.56 & 2.1 \\
\hline 1993 & 25.93 & 0.24 & 0.9 & 24.64 & 95.0 & 0.09 & 0.3 & 0.06 & 0.2 & 0.24 & 0.9 & 0.65 & 2.5 \\
\hline 1994 & 25.91 & 0.18 & 0.7 & 24.65 & 95.1 & 0.10 & 0.4 & 0.07 & 0.3 & 0.23 & 0.9 & 0.68 & 2.6 \\
\hline 1995 & 26.82 & 0.15 & 0.6 & 25.54 & 95.3 & 0.11 & 0.4 & 0.07 & 0.3 & 0.22 & 0.8 & 0.71 & 2.6 \\
\hline 1996 & 27.19 & 0.15 & 0.6 & 26.00 & 95.6 & 0.10 & 0.4 & 0.08 & 0.3 & 0.23 & 0.8 & 0.62 & 2.3 \\
\hline 1997 & 28.91 & 0.15 & 0.5 & 27.02 & 93.5 & 0.09 & 0.3 & 0.09 & 0.3 & 0.24 & 0.8 & 1.31 & 4.5 \\
\hline 1998 & 30.32 & 0.15 & 0.5 & 28.49 & 94.0 & 0.10 & 0.3 & 0.09 & 0.3 & 0.39 & 1.3 & 1.10 & 3.6 \\
\hline 1999 & 33.62 & 0.15 & 0.4 & 30.55 & 90.9 & 0.11 & 0.3 & 0.09 & 0.3 & 0.54 & 1.6 & 2.19 & 6.5 \\
\hline 2000 & 35.59 & 0.19 & 0.5 & 32.49 & 91.3 & 0.08 & 0.2 & 0.07 & 0.2 & 0.54 & 1.5 & 2.21 & 6.2 \\
\hline 2001 & 36.33 & 0.14 & 0.4 & 32.84 & 90.4 & 0.06 & 0.2 & 0.05 & 0.1 & 0.96 & 2.6 & 2.28 & 6.3 \\
\hline 2002 & 36.94 & 0.15 & 0.4 & 33.55 & 90.8 & 0.06 & 0.2 & 0.05 & 0.1 & 0.93 & 2.5 & 2.20 & 6.0 \\
\hline 2003 & 38.03 & 0.10 & 0.3 & 34.58 & 90.9 & 0.08 & 0.2 & 0.03 & 0.1 & 0.56 & 1.5 & 2.68 & 7.0 \\
\hline 2004 & 38.36 & 0.11 & 0.3 & 34.93 & 91.0 & 0.08 & 0.2 & 0.03 & 0.1 & 0.52 & 1.4 & 2.69 & 7.0 \\
\hline 2005 & 38.65 & 0.11 & 0.3 & 34.52 & 89.3 & 0.10 & 0.2 & 0.03 & 0.1 & 0.29 & 0.8 & 3.60 & 9.3 \\
\hline 2006 & 41.14 & 0.11 & 0.3 & 37.04 & 90.0 & 0.10 & 0.2 & 0.03 & 0.1 & 0.35 & 0.9 & 3.52 & 8.6 \\
\hline 2007 & 43.02 & 0.12 & 0.3 & 38.16 & 88.7 & 0.13 & 0.3 & 0.06 & 0.1 & 0.44 & 1.0 & 4.11 & 9.5 \\
\hline 2008 & 46.06 & 0.13 & 0.3 & 41.00 & 89.0 & 0.13 & 0.3 & 0.06 & 0.1 & 0.45 & 1.0 & 4.29 & 9.3 \\
\hline
\end{tabular}

Source: See Table 9. Own calculation.

Table 13: Investment in non-scientific R\&D by industry, 1991-2008

\begin{tabular}{c|ccc}
\hline & AgMin & Manufacturing & FinBsSvc \\
\hline & Mineral exploration & Copyright \& licences & Financial services innovation \\
\hline 1991 & n.a. & n.a. & n.a. \\
1992 & n.a. & 2.9 & n.a. \\
1993 & n.a. & 3.1 & n.a. \\
1994 & 0.05 & 3.43 & n.a. \\
1996 & 0.07 & 3.92 & 3.91 \\
1997 & 0.09 & 4.41 & 3.63 \\
1998 & 0.09 & 4.52 & 4.18 \\
1999 & 0.11 & 6.82 & 5.84 \\
2000 & 0.09 & 5.76 & 6.57 \\
2001 & 0.10 & 5.36 & 5.53 \\
2002 & 0.08 & 5.11 & 4.88 \\
2003 & 0.08 & 4.01 & 5.09 \\
2004 & 0.10 & 4.29 & 4.73 \\
2005 & 0.08 & 3.96 & 4.01 \\
2006 & 0.11 & 4.08 & 4.87 \\
2007 & 0.11 & 3.79 & 4.39 \\
2008 & 0.13 & 3.53 & 4.40 \\
& 0.15 & 3.67 & 3.19 \\
\hline
\end{tabular}

Source: In bn €. See Table 9. Own calculation. 
Table 14: Investment in new architectural and engineering design by industry, 1992-2008

\begin{tabular}{|c|c|c|c|c|c|c|c|c|c|c|c|c|c|}
\hline & \multirow{2}{*}{$\begin{array}{l}\text { Business } \\
\text { Sector }\end{array}$} & \multicolumn{2}{|c|}{ AgMin } & \multicolumn{2}{|r|}{ Mfr. } & \multicolumn{2}{|c|}{ Utility } & \multicolumn{2}{|c|}{ Cons. } & \multicolumn{2}{|c|}{ RetHtTrn } & \multicolumn{2}{|c|}{ FinBsSvc } \\
\hline & & $b n €$ & $\%$ & bn $€$ & $\%$ & $b n €$ & $\%$ & $b n €$ & $\%$ & bn $€$ & $\%$ & $b n €$ & $\%$ \\
\hline 1992 & 17.24 & 0.31 & 1.8 & 6.39 & 37.0 & 0.30 & 1.8 & 0.65 & 3.8 & 2.66 & 15.4 & 6.93 & 40.2 \\
\hline 1993 & 18.05 & 0.32 & 1.8 & 6.47 & 35.8 & 0.33 & 1.8 & 0.74 & 4.1 & 2.68 & 14.8 & 7.52 & 41.7 \\
\hline 1994 & 18.86 & 0.33 & 1.7 & 6.85 & 36.3 & 0.35 & 1.8 & 0.84 & 4.4 & 2.80 & 14.8 & 7.70 & 40.8 \\
\hline 1995 & 18.98 & 0.36 & 1.9 & 7.17 & 37.8 & 0.34 & 1.8 & 0.80 & 4.2 & 2.50 & 13.2 & 7.81 & 41.1 \\
\hline 1996 & 19.09 & 0.36 & 1.9 & 7.34 & 38.5 & 0.35 & 1.9 & 0.86 & 4.5 & 2.56 & 13.4 & 7.62 & 39.9 \\
\hline 1997 & 18.32 & 0.33 & 1.8 & 7.21 & 39.4 & 0.36 & 1.9 & 0.85 & 4.6 & 2.52 & 13.8 & 7.05 & 38.5 \\
\hline 1998 & 18.77 & 0.33 & 1.7 & 7.22 & 38.5 & 0.38 & 2.0 & 0.79 & 4.2 & 2.51 & 13.4 & 7.53 & 40.2 \\
\hline 1999 & 18.50 & 0.26 & 1.4 & 7.23 & 39.1 & 0.39 & 2.1 & 0.78 & 4.2 & 2.56 & 13.8 & 7.28 & 39.3 \\
\hline 2000 & 18.55 & 0.28 & 1.5 & 7.22 & 38.9 & 0.34 & 1.8 & 0.71 & 3.8 & 2.59 & 14.0 & 7.41 & 40.0 \\
\hline 2001 & 18.94 & 0.27 & 1.4 & 7.37 & 38.9 & 0.36 & 1.9 & 0.65 & 3.4 & 2.59 & 13.7 & 7.71 & 40.7 \\
\hline 2002 & 18.44 & 0.27 & 1.5 & 7.07 & 38.3 & 0.37 & 2.0 & 0.56 & 3.0 & 2.50 & 13.5 & 7.67 & 41.6 \\
\hline 2003 & 17.81 & 0.30 & 1.7 & 6.71 & 37.7 & 0.31 & 1.8 & 0.54 & 3.0 & 2.36 & 13.3 & 7.58 & 42.6 \\
\hline 2004 & 17.42 & 0.30 & 1.7 & 6.62 & 38.0 & 0.30 & 1.7 & 0.53 & 3.0 & 2.46 & 14.1 & 7.22 & 41.4 \\
\hline 2005 & 18.17 & 0.30 & 1.7 & 6.81 & 37.5 & 0.30 & 1.7 & 0.56 & 3.1 & 2.55 & 14.1 & 7.65 & 42.1 \\
\hline 2006 & 19.06 & 0.36 & 1.9 & 7.08 & 37.2 & 0.31 & 1.6 & 0.61 & 3.2 & 2.64 & 13.9 & 8.06 & 42.3 \\
\hline 2007 & 20.31 & 0.38 & 1.9 & 7.54 & 37.2 & 0.33 & 1.6 & 0.65 & 3.2 & 2.82 & 13.9 & 8.59 & 42.3 \\
\hline 2008 & 22.19 & 0.42 & 1.9 & 8.24 & 37.2 & 0.36 & 1.6 & 0.71 & 3.2 & 3.08 & 13.9 & 9.38 & 42.3 \\
\hline
\end{tabular}

Source: See Table 9. Own calculation.

Table 15: Investment in marketing and human capital by industry, 1994-2008

\begin{tabular}{|c|c|c|c|c|c|c|c|c|c|c|c|c|c|}
\hline & \multirow[t]{2}{*}{ B.Sector } & \multicolumn{2}{|c|}{ AgMin } & \multicolumn{2}{|r|}{ Mfr. } & \multicolumn{2}{|c|}{ Utility } & \multicolumn{2}{|c|}{ Cons. } & \multicolumn{2}{|c|}{ RetHtTrn } & \multicolumn{2}{|c|}{ FinBsSvc } \\
\hline & & $b n €$ & $\%$ & $b n €$ & $\%$ & $b n €$ & $\%$ & $b n €$ & $\%$ & $b n €$ & $\%$ & bn $€$ & $\%$ \\
\hline & \multicolumn{13}{|c|}{ Investment in Brand Equity } \\
\hline 1994 & 19.99 & 0.34 & 1.7 & 7.26 & 36.3 & 0.37 & 1.8 & 0.89 & 4.4 & 2.96 & 14.8 & 8.16 & 40.8 \\
\hline 1995 & 20.84 & 0.40 & 1.9 & 7.87 & 37.8 & 0.37 & 1.8 & 0.88 & 4.2 & 2.75 & 13.2 & 8.57 & 41.1 \\
\hline 1996 & 21.17 & 0.40 & 1.9 & 8.14 & 38.5 & 0.39 & 1.9 & 0.95 & 4.5 & 2.84 & 13.4 & 8.45 & 39.9 \\
\hline 1997 & 21.50 & 0.39 & 1.8 & 8.46 & 39.4 & 0.42 & 1.9 & 1.00 & 4.6 & 2.96 & 13.8 & 8.27 & 38.5 \\
\hline 1998 & 22.22 & 0.39 & 1.7 & 8.55 & 38.5 & 0.45 & 2.0 & 0.94 & 4.2 & 2.98 & 13.4 & 8.92 & 40.2 \\
\hline 1999 & 23.16 & 0.33 & 1.4 & 9.06 & 39.1 & 0.49 & 2.1 & 0.97 & 4.2 & 3.20 & 13.8 & 9.11 & 39.3 \\
\hline 2000 & 24.22 & 0.37 & 1.5 & 9.42 & 38.9 & 0.44 & 1.8 & 0.92 & 3.8 & 3.38 & 14.0 & 9.68 & 40.0 \\
\hline 2001 & 23.03 & 0.33 & 1.4 & 8.96 & 38.9 & 0.43 & 1.9 & 0.78 & 3.4 & 3.15 & 13.7 & 9.38 & 40.7 \\
\hline 2002 & 21.82 & 0.32 & 1.5 & 8.37 & 38.3 & 0.44 & 2.0 & 0.66 & 3.0 & 2.95 & 13.5 & 9.07 & 41.6 \\
\hline 2003 & 21.40 & 0.37 & 1.7 & 8.06 & 37.7 & 0.38 & 1.8 & 0.65 & 3.0 & 2.84 & 13.3 & 9.11 & 42.6 \\
\hline 2004 & 21.99 & 0.38 & 1.7 & 8.36 & 38.0 & 0.38 & 1.7 & 0.66 & 3.0 & 3.10 & 14.1 & 9.11 & 41.4 \\
\hline 2005 & 21.98 & 0.36 & 1.7 & 8.24 & 37.5 & 0.36 & 1.7 & 0.67 & 3.1 & 3.09 & 14.1 & 9.26 & 42.1 \\
\hline 2006 & 22.45 & 0.42 & 1.9 & 8.34 & 37.2 & 0.37 & 1.6 & 0.72 & 3.2 & 3.11 & 13.9 & 9.49 & 42.3 \\
\hline 2007 & 22.90 & 0.43 & 1.9 & 8.51 & 37.2 & 0.37 & 1.6 & 0.73 & 3.2 & 3.18 & 13.9 & 9.68 & 42.3 \\
\hline \multirow[t]{2}{*}{2008} & 22.97 & 0.43 & 1.9 & 8.53 & 37.2 & 0.37 & 1.6 & 0.73 & 3.2 & 3.18 & 13.9 & 9.71 & 42.3 \\
\hline & \multicolumn{13}{|c|}{ Investment in Human Capital } \\
\hline 1995 & 30.30 & 0.40 & 1.3 & 9.73 & 32.1 & 0.70 & 2.3 & 1.32 & 4.3 & 7.33 & 24.2 & 10.82 & 35.7 \\
\hline 1996 & 32.47 & 0.35 & 1.1 & 10.61 & 32.7 & 0.75 & 2.3 & 1.39 & 4.3 & 8.10 & 24.9 & 11.27 & 34.7 \\
\hline 1997 & 32.17 & 0.30 & 0.9 & 11.52 & 35.8 & 0.81 & 2.5 & 1.38 & 4.3 & 8.09 & 25.2 & 10.06 & 31.3 \\
\hline 1998 & 33.86 & 0.21 & 0.6 & 12.64 & 37.3 & 0.81 & 2.4 & 1.63 & 4.8 & 8.07 & 23.8 & 10.49 & 31.0 \\
\hline 1999 & 30.63 & 0.17 & 0.5 & 9.87 & 32.2 & 0.68 & 2.2 & 1.45 & 4.7 & 9.44 & 30.8 & 9.03 & 29.5 \\
\hline 2000 & 32.95 & 0.16 & 0.5 & 10.64 & 32.3 & 0.63 & 1.9 & 1.32 & 4.0 & 9.32 & 28.3 & 10.87 & 33.0 \\
\hline 2001 & 34.54 & 0.24 & 0.7 & 11.59 & 33.5 & 0.77 & 2.2 & 1.38 & 4.0 & 9.25 & 26.8 & 11.31 & 32.7 \\
\hline 2002 & 35.69 & 0.27 & 0.8 & 12.07 & 33.8 & 0.86 & 2.4 & 1.49 & 4.2 & 9.83 & 27.5 & 11.17 & 31.3 \\
\hline 2003 & 32.14 & 0.20 & 0.6 & 10.70 & 33.3 & 0.84 & 2.6 & 1.39 & 4.3 & 9.28 & 28.9 & 9.73 & 30.3 \\
\hline 2004 & 32.49 & 0.18 & 0.6 & 11.13 & 34.3 & 0.90 & 2.8 & 1.41 & 4.3 & 8.95 & 27.6 & 9.91 & 30.5 \\
\hline 2005 & 34.21 & 0.24 & 0.7 & 10.99 & 32.1 & 1.08 & 3.2 & 1.49 & 4.4 & 8.67 & 25.3 & 11.73 & 34.3 \\
\hline 2006 & 35.63 & 0.22 & 0.6 & 10.81 & 30.3 & 1.18 & 3.3 & 1.52 & 4.3 & 9.07 & 25.4 & 12.82 & 36.0 \\
\hline
\end{tabular}

Source: See Table 9. Own calculation. Marketing consists of investment for advertising and market research. 
Table 16: Investment in organizational capital by industry, 1991-2008

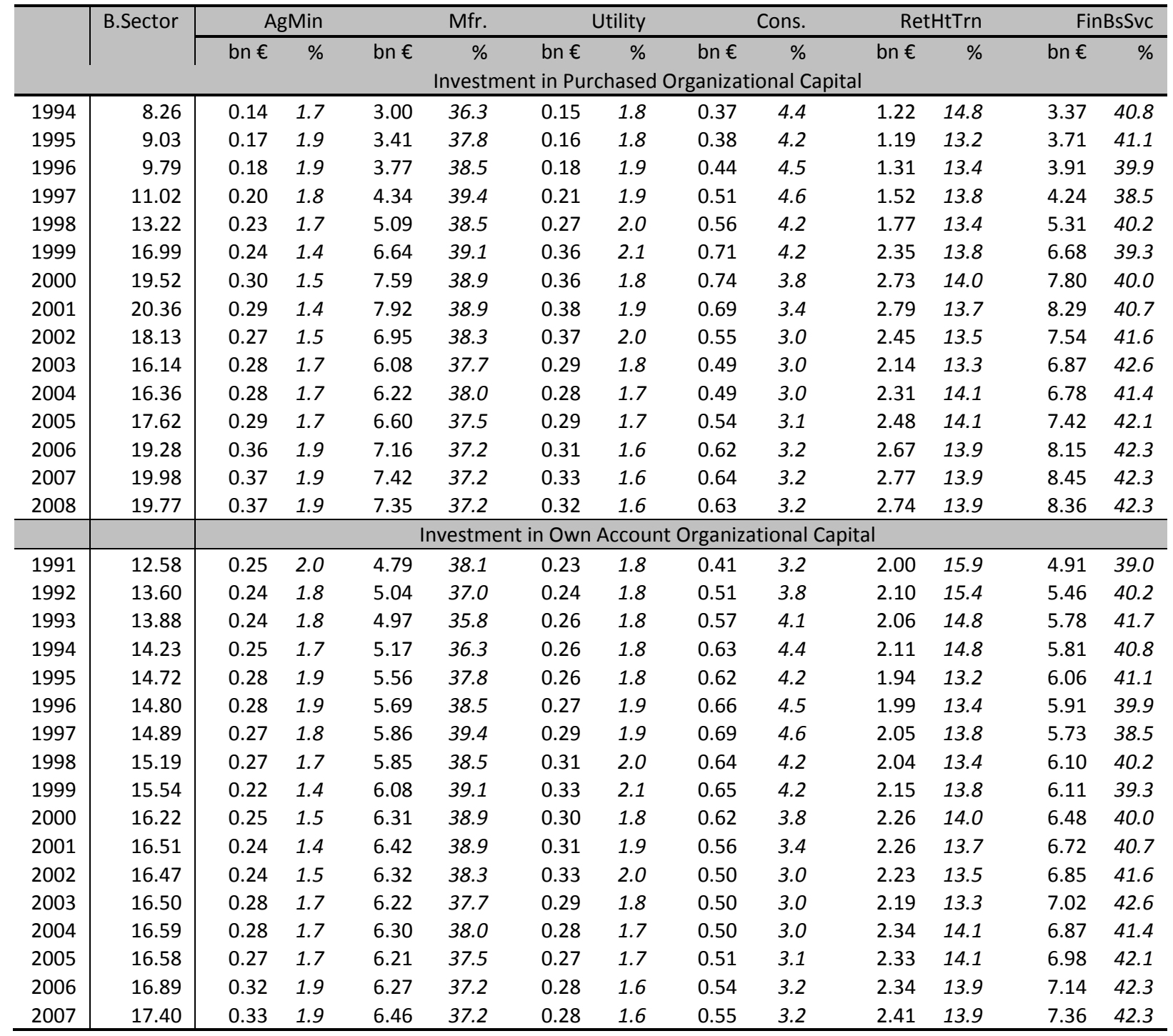

Source: See Table 9. Own calculation. 
Table 17:

Depreciation rates for growth accounting

\begin{tabular}{|c|c|}
\hline Asset & Depreciation Rate \\
\hline \multicolumn{2}{|l|}{ Intangible Assets } \\
\hline Software & 0.315 \\
\hline Databases & 0.315 \\
\hline Scientific R\&D & 0.2 \\
\hline Mineral exploration & 0.2 \\
\hline Copyright licences & 0.2 \\
\hline Financial services innovation & 0.2 \\
\hline Architectural and engineering design & 0.2 \\
\hline Advertising & 0.6 \\
\hline Market research & 0.6 \\
\hline Firm-specific human capital & 0.4 \\
\hline Organizational structure & 0.4 \\
\hline \multicolumn{2}{|l|}{ Tangible Assets } \\
\hline Computing equipment (IT) & 0.315 \\
\hline Communications equipment (CT) & 0.115 \\
\hline \multicolumn{2}{|l|}{ Transport equipment (TraEq) } \\
\hline Agriculture, Fishing \& Mining & 0.170 \\
\hline Manufacturing & 0.177 \\
\hline Electricity, Gas \& Water Supply & 0.191 \\
\hline Construction & 0.195 \\
\hline Trade, Hotels \& Rest., Transp. \& Comm. & 0.190 \\
\hline Financial \& Business Services & 0.190 \\
\hline \multicolumn{2}{|l|}{ Other machinery and equipment (OMach) } \\
\hline Agriculture, Fishing \& Mining & 0.129 \\
\hline Manufacturing & 0.109 \\
\hline Electricity, Gas \& Water Supply & 0.094 \\
\hline Construction & 0.139 \\
\hline Trade, Hotels \& Rest., Transp. \& Comm. & 0.126 \\
\hline Financial \& Business Services & 0.146 \\
\hline \multicolumn{2}{|l|}{ Non-resident structures (OCon) } \\
\hline Agriculture, Fishing \& Mining & 0.024 \\
\hline Manufacturing & 0.033 \\
\hline Electricity, Gas \& Water Supply & 0.023 \\
\hline Construction & 0.034 \\
\hline Trade, Hotels \& Rest., Transp. \& Comm. & 0.029 \\
\hline Financial \& Business Services & 0.038 \\
\hline
\end{tabular}

